\section{Ankara Üniversitesi Eğitim Bilimleri Fakültesi Özel Eğitim Dergisi}

2022, 23(1), 133-164
ARAŞTIRMA

Gönderim Tarihi: 26.08.20

Kabul Tarihi: 30.05.21

Erken Görünüm: 10.07.21

\title{
COVID-19 Salgınında Türkiye’deki Özel Gereksinimi Olan Öğrenciler ve Ailelerine Yönelik Uzaktan Özel Eğitim Uygulamalarına İlişsin Uzman Bakış Açısı
}

\author{
Sunagül Sani-Bozkurt ${ }^{\text {iD }} 1$ \\ Gizem Yıldız iD 4 \\ Çiğdem Uysal ${ }^{1} 7$ \\ Özlem Diken 10 \\ Murat Doğan 13
}

\author{
Gülden Bozkuş-Genç (iD) \\ Seçil Celik 5 \\ Hasan Gürgür iD 8 \\ Nazmiye Nazlı Ateşgöz 11 \\ Pınar Şafak 14
}

\author{
Sezgin Vuran 3 \\ İbrahim H. Diken (iD6 \\ Gülefşan Özge Kalaycı 9 \\ Rifat İçüz 12 \\ Pınar Demiryürek 15
}

Öz

Giriș: Koronavirüs (COVID-19) sırasında okullar kapatıldığında değişen yaşantılar yalnızca özel gereksinimi olan öğrencileri değil beraberinde ailelerini de olumsuz yönde etkilemiştir. Araştırmada COVID-19 salgını kısıtlama sürecinde Türkiye'de farklı özel gereksinimi olan öğrenciler ve ailelerine yönelik gerçekleştirilen uzaktan özel eğitim uygulamalarının uzman bakış açısı ile ortaya konması amaçlanmıştır.

Yöntem: Kolektif durum çalışması olarak planlanan bu araştırmada kendi deneyimlerini ve gözlemlerini bildirmek üzere toplam 15 akademisyen araştırmanın doğrudan katılımcısı olmuştur. Araştırma bağlamında akademisyenler tarafından elde edilen bilgiler süzgeçten geçirilerek, farklılıklar ve örüntüler aranmış, gözlemler ve deneyimler heuristic (öz deneyimsel) bakış açısı ile yansıtılarak kaleme alınmıştır.

Bulgular: Araştırmanın sonuçlarına göre; Türkiye'de uzaktan eğitime geçişin hızlı bir şekilde devreye girmesiyle beraber özel gereksinimi olan öğrenciler ve ailelerine yönelik uzaktan eğitime dayalı uygulamaların resmi, özel kurum ve şahıslar tarafından sunulduğu görülmüştür. Ancak uygulamalar ülke geneline yaygınlaştırılabilecek biçimde sistemli olmamakla birlikte her bir yetersizlik grubu için mobil uygulamaların zenginleştirilmesi, kurumsal platformda aile odaklı destek mekanizmalarının oluşturulması gibi bu süreçten çıkarılması gereken dersler olduğu da açıça ortaya konmuştur. Ayrıca özellikle resmi kurumlar tarafından sunulan iyi uygulama örneklerinin salgın sonrasında devam etmesi gerektiği sonucuna ulaşılmıştır.

Tartışma: Araştırma sonuçlarının başta Türkiye olmak üzere farklı ülkelerde özel eğitim uygulamalarının planlanmasında ileriye dönük bir yol haritası çizilmesine yardımcı olabileceği öngörülmektedir. Türkiye'de kısıtlama sürecinde uzaktan eğitime geçişe hızlı bir tepkiyle yanıt verildiği ve bu süreçte iyi uygulama örneklerinin olduğu söylenebilmektedir. Çalışmada karar vericilere, okul, kurum ve uzmanlara, ailelere ve yeni normale yönelik öneriler sunulmuştur.

Anahtar sözcükler: Koronavirüs, COVID-19, uzaktan eğitim, acil uzaktan öğretim, özel gereksinimi olan öğrenciler, psikososyal destek, özel eğitim.

Atıf için: Sani-Bozkurt, S., Bozkuş-Genç, G., Vuran, S., Yıldız, G., Çelik, S., Diken, İ. H., Uysal, Ç., Gürgür, H., Kalaycı, G. Ö., Diken, Ö., Ateşgöz, N. N., İçyüz, R., Doğan, M., Şafak, P., \& Demiryürek, P. (2022). COVID-19 salgınında Türkiye'deki özel gereksinimi olan öğrenciler ve ailelerine yönelik uzaktan özel eğitim uygulamalarına ilișkin uzman bakış açısı. Ankara Üniversitesi Ĕgitim Bilimleri Fakültesi Özel Eğitim Dergisi, 23(1), 133-164. https://doi.org/10.21565/ozelegitimdergisi.786118

\footnotetext{
${ }_{1}^{1}$ Sorumlu Yazar: Dr. Öğr. Üyesi, Anadolu Üniversitesi, E-posta: ssbozkurt@ anadolu.edu.tr, https://orcid.org/0000-0001-6648-9636

${ }^{2}$ Dr. Öğr. Üyesi, Anadolu Üniversitesi, E-posta: guldenbozkus@anadolu.edu.tr, https://orcid.org/0000-0002-9444-7393

${ }^{3}$ Prof. Dr., Anadolu Üniversitesi, E-posta: svuran@anadolu.edu.tr, https://orcid.org/0000-0001-7658-1102

${ }^{4}$ Dr., Anadolu Üniversitesi, E-posta: gizemy@ anadolu.edu.tr, https://orcid.org/0000-0003-2693-6264

${ }^{5}$ Dr., Anadolu Üniversitesi, E-posta: secilcelik@ anadolu.edu.tr, https://orcid.org/0000-0002-1393-3382

${ }^{6}$ Prof. Dr., Anadolu Üniversitesi, E-posta: ihdiken@anadolu.edu.tr, https://orcid.org/0000-0002-5761-2900

${ }^{7}$ Arş. Gör., Anadolu Üniversitesi, E-posta: cigdemkol@ anadolu.edu.tr, https://orcid.org/0000-0002-7884-8728

${ }^{8}$ Prof. Dr., Anadolu Üniversitesi, E-posta: hasangurgur@anadolu.edu.tr, https://orcid.org/0000-0002-4016-4048

${ }^{9}$ Arş. Gör., Anadolu Üniversitesi, E-posta: gulefsanozgeakbey@anadolu.edu.tr, https://orcid.org/0000-0002-7627-8477

${ }^{10}$ Prof. Dr., Anadolu Üniversitesi, E-posta: odogramaci@anadolu.edu.tr, https://orcid.org/0000-0003-1676-7989

${ }^{11}$ Dr. Öğr. Üyesi, Anadolu Üniversitesi, E-posta: nazmiyeo@ anadolu.edu.tr, https://orcid.org/0000-0001-5944-937X

${ }^{12}$ Arş. Gör., Anadolu Üniversitesi, E-posta: rifaticyuz@ anadolu.edu.tr, https://orcid.org/0000-0003-1279-3936

${ }^{13}$ Doç. Dr., Anadolu Üniversitesi, E-posta: mudogan@anadolu.edu.tr, https://orcid.org/0000-0003-4942-3760

${ }^{14}$ Doç. Dr., Gazi Üniversitesi, E-posta: apinar@gazi.edu.tr, https://orcid.org/0000-0002-3386-9816

${ }^{15}$ Arş. Gör., Gazi Üniversitesi, E-posta: pdemiryurek@gazi.edu.tr, https://orcid.org/0000-0003-1035-5246
} 


\section{Giriș}

Çin'in Hubei eyaletinin Wuhan şehrinde ortaya çıkan ve çok kısa bir sürede hızla yayılan koronavirüs (COVID-19) Dünya Sağlık Örgütü tarafından 11 Mart 2020'de küresel salgın olarak ilan edilmiştir (World Health Organization [WHO], 2020). Milyonlarca insanın mücadele ettiği COVID-19 daha önce eşi benzeri görülmemiş bir acil müdahale ve olağanüstü küresel dayanışma gerektirmiş (Callaway \& Li, 2020; Ting vd., 2020; United Nations Educational, Scientific and Cultural Organization [UNESCO], 2020a) ve farklı ülkelerdeki hükümet yetkilileri tarafından COVID-19'un daha geniş bir alana yayılmasına karşı çeşitli önlemler alınmıştır (Cascella vd., 2020; Ting vd., 2020). Türkiye'de ise ilk vakanın 11 Mart 2020'de ilan edilmesiyle (Koca, 2020) salgının yayılmasının önlenmesi amacıyla uluslararası uçuş kısıtlamaları, yurt dışından gelenler için karantina uygulamaları, okulların ve eğitim kurumlarının tatil edilmesi, toplu yaşam alanlarının kapatılması, uygun sektörler için evden çalışma ve belli yaş gruplarına sokağa çıkma kısıtlaması şeklinde acilen bir dizi tedbir alınmıştır (Bilim Kurulu, 2020; Sancak \& Çöl, 2020). İçinde bulunduğumuz mevcut durumda da söz konusu tedbirler salgının daha da zayıflamasını sağlamak için ya da kötü senaryo olarak yeni bir dalga olasılığına karşı farklı boyutta da olsa sürmektedir. Bu süreç “yeni normal” şeklinde adlandırılmıştır (Bozkurt vd., 2020).

COVID-19 salgını, ölçeği ve etkisi nedeniyle tüm dünyada ilk kez yalnızca halk sağlığını etkilemekle kalmamış (Organisation for Economic Cooperation and Development [OECD], 2020) günlük yaşamımızın her alanını büyük ölçüde etkilemiştir. Bu anlamda eğitim, COVID-19 salgınından en çok etkilenen alanlardan biri olmuştur (Bozkurt vd., 2020; UNESCO, 2020a, 2020b). COVID-19 küresel salgınının yayılmasını yavaşlatmak için tüm dünyada hemen tüm düzeylerde eğitim kurumları da kapatılmıştır. Dolayısıyla dünya genelinde yaklaşık olarak öğrenci nüfusunun \%90'1na eşit olan 1.6 milyar öğrencinin eğitimi kesintiye uğramıştır (UNESCO, 2020a; 2020b; United Nations Children's Fund [UNICEF], 2020). Ulusal eğitim sistemlerinin karş1laştığı en büyük zorluk olan COVID-19'un eğitime erişim üzerindeki bu büyük etkisi, tüm dünyadaki eğitim yetkilileri üzerinde büyük bir baskı yaratmıştır. Halen Türkiye de dâhil çoğu ülke, eğitim süreçlerini sürdürmek, uzaktan eğitim platformları oluşturmak, güncellemek ve geliştirmek için çaba sarf etmektedir (Goldschmidt, 2020; OECD, 2020; Özer, 2020).

Uzaktan eğitime ani ve acil geçişle birlikte sosyal izolasyona yönelik önlemler, tipik gelişim gösteren öğrenciler ve ailelerini etkilese de özel gereksinimi olan öğrenciler ve aileleri için çok daha özel zorluklar ortaya koymuştur. Özel gereksinimi olan bir çocuğa sahip olmak ve eğitsel süreçlerinde aktif rol oynamak, gereksinimlerine göre birtakım özel planlamalar gerektirmesi nedeniyle tipik gelişim gösteren bir çocuğa sahip olmaktan ve eğitsel süreçlerinde aktif rol almaktan daha güç olmaktadır. Özel gereksinimi olan çocukların ailelerinin normal zamanlarda bile tipik gelişim gösteren çocukları olanlardan daha fazla stresle karşılaştıkları bilinmektedir (McConnell \& Savage, 2015; McStay vd., 2014). Kisitlama sürecinde hayatın ne zaman "normale" döneceği konusundaki belirsizlikler öğrenciler ve ailelerin kaygı düzeylerini artırmaktadır (Fiorillo \& Gorwood, 2020). COVID-19 salgını şüphesiz özel gereksinimi olan pek çok öğrencinin güçlüklerini artırabilecek hızla değişen sosyal bir duruma yol açmıştır (Colizzi vd., 2020; Stankovic vd., 2020). Yalnızca okulda bulunan ekipmanlara, materyallere ve profesyonel destek erişimine bağlı farklı gelişimsel gereksinimleri olan öğrencilerin okulların kapanması ve kısıtlamalar nedeniyle tipik gelişim gösteren akranlarından çok daha ciddi bir şekilde olumsuz etkilenebileceklerini söylemek mümkündür (Kuper vd., 2020).

COVID-19 sırasında okullar kapatıldığında değişen yaşantılar yalnızca özel gereksinimi olan öğrencileri değil beraberinde ailelerini de olumsuz yönde etkilemiştir (Asbury vd., 2020). Aileler çocuklarının evde eğitim sürecinde var olan beceri ve davranışlarının gerilemesinden endişe duymanın yanı sıra çocuklarının uyku sorunu ve davranış problemlerinin artması nedeniyle bu süreçle baş etmede kendilerini yalnız ve çaresiz hissetmişlerdir (Stankovic vd., 2020). Alanyazın incelendiğinde ebeveynlerin, günlük sorumluluklarına salgın sürecinde ortaya çıkan çocuklarının eğitim rollerinin de eklenmesi ile aşırı yük altında kaldığı kabul görmekte ve aile üyelerinin büyük bir bölümünün travma, psikolojik baskı ve çeşitli düzeylerde kaygı yaşadıkları belirtilmektedir (Bozkurt vd., 2020; Cluver vd., 2020; Stankovic vd., 2020). Tüm bunların yanı sıra bir de düşük sosyo-ekonomik düzey ve farklı yaşantıları olan çocuklar ve aileler için ise bilinmezliklerle dolu bir sürecin etkileri daha da yıkıcı olabilmektedir (Cluver vd., 2020; Nicola vd., 2020). Aileler çeşitli sosyo-demografik değişkenlere, ev yaşamına, özellikle de toplumsal cinsiyet rol ve görevlerine bağlı olarak böyle bir süreçten psiko-sosyal bağlamda oldukça etkilenmektedir (Işıı \& Akbaş, 2019).

Kısıtlamanın ötesinde, evde eğitim süreci halen devam etmekte olup yakın gelecekte okula dönmeye hazırlanan öğrencilerin ve ailelerin destek gereksinimlerini anlamak (Toseeb vd., 2020) ve uzaktan sunulacak özel eğitim uygulamalarının daha geniş perspektiften ele alınması için yeni normunu şekillendirmek gerekecektir. Özel gereksinimi olan öğrencilerin ve ailelerinin gereksinimleri temel alınarak hazırlıklar ve güncellemelerin 
yapılabilmesi için mevcut durumdan dersler çıkarmış olmak gerekmektedir. Öte yandan salgııın yeni dalgalarının ortaya çıkma olasılığının yüksek olduğu düşünüldüğünde, tedbir amaçlı sürece hazırlanmanın gerekliliği vurgulanabilir. Bunun için COVID-19 kısttlama sürecinde uzaktan sunulan özel eğitim uygulamalarıyla ilgili mevcut çalışmaların eksik ve güçlü yanlarını ortaya koymaya yönelik durumu özetleyen ve sentezleyen kapsamlı çalışmalara ivedilikle gereksinim duyulmaktadır. Bu sürecin en önemli paydaşları olarak karar vericilere, $\mathrm{okul} /$ kurum yetkililerine, öğretmen/uzmanlara ve ailelere uzaktan eğitimle gerçekleştirilecek uygulamaları ele alma konusunda bilimsel dayanaklı bir rehber sunmak son derece önem arz etmektedir. Böylece var olan durumun ortaya konulmasıyla birlikte, gelecekte yaşanacak yeni salgın durumlarında neler yapılabileceğine ilişkin temel bir çerçeve de çizilmiş olacaktır. Bu gerekçeden hareketle bu araştırmanın amacı; COVID-19 salgını kısıtlama sürecinde Türkiye'de farklı özel gereksinim durumlarına (otizm spektrum bozukluğu [OSB], zihin yetersizliği, işitme yetersizliği, görme yetersizliği, dil ve konuşma bozukluğu, dikkat eksikliği ve hiperaktivite bozukluğu [DEHB] ve özel yetenek) yönelik gerçekleştirilen özel eğitim uygulamalarının neler olduğunun uzman bakış açısıyla ortaya konmasıdır. Bu amaçla aşağıdaki araştırma sorularına yanıt aranmıştır:

1. Farklı özel gereksinim gruplarında uzaktan eğitim alanında gerçekleştirilen uygulamalar nelerdir?

2. Farklı özel gereksinim gruplarında uzaktan eğitim sürecinde psiko-sosyal bağlamda gerçekleştirilen uygulamalar nelerdir?

3. Farklı özel gereksinim gruplarında uzaktan eğitim uygulamaları kapsamında salgından çıkarılması gereken dersler nelerdir?

\section{Yöntem}

\section{Araștırma Modeli}

$\mathrm{Bu}$ araştırmada nitel araştırma yaklaşımlarından biri olan kolektif durum çalışması (Stake, 1995) benimsenmiştir. Kolektif durum çalışması olarak yürütülen araştırmada yedi özel gereksinim grubuna yönelik her katkı aynı üç alt başlıkta incelenerek, okuyucuların durumları birbirinden bağımsız incelenmelerine ya da birbirleriyle karşılaştırmalarına olanak sağlanmıştır (Bartlett \& Vavrus, 2016; Stake, 1995). Bu kapsamda çalışmada OSB, zihin yetersizliği, işitme yetersizliği ve görme yetersizliği, dil ve konuşma bozukluğu, DEHB olan ve özel yetenekli çocuklar bağlamında yedi durum incelenmiştir. Bunun için her durum kısıtlama sürecinde "uzaktan eğitimde yansımalar", "psiko-sosyal destekte yansımalar" ve "salgından çıkarılması gereken dersler" bağlamında özel gereksinim şemsiyesi altında alan uzmanlarının görüşleri doğrultusunda ele alınmıştır.

\section{Katılımelar}

Araştırma sürecinde her bir duruma ilişkin kendi deneyimlerini ve gözlemlerini bildirmek üzere ilgili yetersizlik grubunun eğitimi alanında yaklaşık 6-30 yıl arasında deneyimi olan araştırmacı ve uygulamacı kimliğine sahip toplam 15 kişilik akademisyen grubu yer almıştır. Bu kişiler aynı zamanda makalenin yazarlarıdır. Akademisyen grubunun geniş tutulmasının amacı araştırma konusu bağlamında çok sayıda araştırmacı gözlemi ve çoğulcu bir bakış açısı sunmaktır. Bu araştırmada araştırmacıların her biri araştırmanın doğrudan katılımcısıdır. Çalışmanın katılımcıları olan uzman grubu; salgın sürecinde alanındaki gelişmeleri ve gündemi yakından takip eden, süreç içerisinde kendisine ulaşan aile, öğretmen ya da ilgili uzmanlar ile iş birliği yapan, uzaktan destek sunan, süreci gözlemleyen kısacası halihazırda bu sürece ilişkin tecrübeleri olan akademisyenlerden oluşmaktadır.

\section{Veri Toplama ve Analizi}

$\mathrm{Bu}$ araş̧ırmada veriler durum ile deneyimi olan uzmanlardan toplanmıştır. Araştırmacılar gözlem ve deneyimlerini aktarmak için salgın sürecinde kendilerine ulaşan aile, öğretmen/uzman, öğrenci ve kurum koordinatörleri ile telefon görüşmeleri/sohbetlerinden yararlanmış ve ayrıca kurum web siteleri, yazılı raporlar, dokümanlar, arşiv kayıtları, öğrenci ürünleri (ör. sanat eserleri, oluşturulan materyaller ve çalışmada kullanılabilecek diğer fiziksel kanıtlar), fotoğraflar, video kayıtları ve sosyal medya platformlarından yararlanmışlardır.

Veri toplama sürecinin ardından akademisyenler tarafindan elde edilen bilgiler süzgeçten geçirilerek, farklılıklar ve örüntüler aranmış, gözlemler ve deneyimler heuristic (öz deneyimsel) bakış açısı ile yansıtılarak kaleme alınmıştır. Heuristic, bilinmeyen bir fenomenin anlamını ve yapısını; öz yansıtım, keşfetme ve açıklama gibi içsel yollarla anlatmaya çalışan bir yaklaşımı benimsemektedir (Douglass \& Moustakas, 1985). Bu yaklaşıma göre araştırma süreci ve ilgili kavramlar; araştırmanın odak noktasını tanımlama, içsel diyalog, içsel biliş, öngörü, konuyu oturtma, odaklanma ve içsel referans çerçevesi oluşturma şeklindedir (Moustakas, 1990). Bu bağlamda bu 
çalışma kapsamında aynı zamanda araştırmacı olan katılımcıların araştırma sürecinin içinde yer alması (Djuraskovic \& Arthur, 2011) deneyim yoluyla yaşadıkları içsel süreci daha iyi yansıtması ve söz konusu durumlara anlam yüklemesi açısından önemlidir (Douglass \& Moustakas, 1985). Heuristic bir yolun benimsendiği araştırmada veri toplama ve analiz sürecine ilişkin izlenen süreç Şekil 1'de yer almaktadır.

\section{Şekil 1}

Veri Toplama ve Analiz Süreci

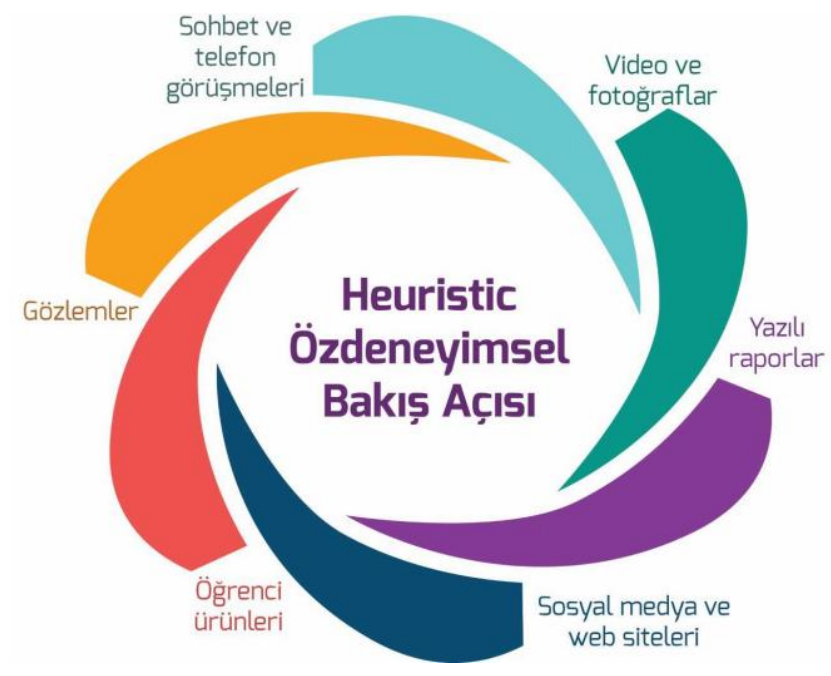

\section{Nitel Araştırmalarda Geçerlik ve Güvenirlik}

Diğer nitel araştırma desenlerinde olduğu gibi durum çalışmalarında da veri toplama sürecinde araştırmacının rolü çok önemlidir. Bu çalışmada yer alan araştırmacılar yedi farklı özel gereksinim grubu ve/veya nitel araştırmalar üzerine farklı akademik çalışmaları olan araştırmacılardır. Araştırmacıların Türkiye bağlamında içsel bir bakış açısı sunmasının ve bulguların ilk kaynaktan sağlanarak çözümlenmesinin çalışmayı ayrıca güçlendirdiği düşünülmektedir. Ayrıca araştırmadaki akademisyen ekibi dışında nitel araştırma konusunda farklı bir akademisyen gözünden araştırma metninin okunması sağlanmış ve bu doğrultuda gerekli düzenlemeler dikkate alınmıştır.

Nitel çalışmalarda geçerliliği sağlamanın yollarından birisi de verilerin ayrıntılı olarak rapor edilmesidir (Yıldırım \& Şimşek, 2016). Bu bağlamda araştırmanın amacı doğrultusunda video kayıtları, kurum örnekleri, yazılı ve sözlü raporlar detaylı bir şekilde incelenerek raporlanmış ve okuyucuların da kendi yorumlarını katabilecekleri nitelikte veri sağlanmıştır. Nitel çalışmalarda güvenirliği artırmak amacıyla faydalanılan yaklaşımlardan bir diğeri de çeşitlemedir (Seggie vd., 2017; Yıldırım \& Şimşek, 2016). Bu çalışma bağlamında araştırmanın amacına uygun 15 farklı akademisyen bakış açısı ile araştırmacı çeşitlemesi yapılmış ayrıca farklı gruplardan, farklı çevrelerden ve farklı zamanlarda veri toplama tekniği kullanılarak veri çeşitlemesi yapılmıştır.

\section{Bulgular}

$\mathrm{Bu}$ araştırmada yedi durumda ele alınan yansımalar; uzaktan eğitimde yansımalar ve psiko-sosyal destekte yansımalar başlıklarında açıklanmış olup bu süreçte her iki başlık altında ortaya çıkan durumlar çıkarılan dersler başlı̆̆ında değerlendirilmiştir. Türkiye'de Milli Eğitim Bakanlığı (MEB) tarafindan atılan adımların bu uygulamaların geliştirilmesinde öncü olduğu görülmektedir. Bu nedenle bulgularda MEB Eğitim Bilişim Ağı (EBA) yedi durum için de ortak noktayı oluşturmakla birlikte her bir durum için ayrı ayrı yansımalarının neler olduğu değerlendirilmiştir. Ayrıca bu süreçte öne çıkan vakıf, dernek vb. kurum ve kuruluşların (ör. Bilim Kahramanları Derneği, Bilim Deney Merkezi, Türkiye Down Sendromu Derneği, Tohum Otizm Vakfi) çalışmaları da değerlendirilmiştir. 


\section{Durum 1: Otizm Spektrum Bozukluğu}

\section{Uzaktan Ĕgitimde Yansımalar}

MEB ve doğrudan OSB olan öğrencilere hizmet veren öncü sivil toplum kuruluşları (STK); çevrimiçi web seminerleri, kaynaklara ilişkin bağlantı paylaşımı, seminerlerin kayıtlarına YouTube kanalından erişim, söyleşiler, aile eğitimleri, farkındalık çalışmaları yürütmüşlerdir. OSB olan öğrenciler söz konusu olduğunda ise doğrudan bu öğrencilere yönelik program ve materyallerin oldukça sınırlı olduğu söylenebilir. OSB olan öğrencilere içerikler görsel destekler ve etkileşime dayalı uygulamalar aracıllğıyla sunulmuştur. Türkiye'nin koşulları düşünüldüğünde şehir merkezlerinde internete erişim kırsal alanlara göre daha kolaydır. Bu nedenle, internet olanağı olmayan öğrenciler için televizyon (TV) yayınları kullanılmıştır. Daha çok bilgilendirme, yönlendirme şeklinde evde eğitimin sürdürülebilirliğini sağlamaya yönelik yapılan çalışmaların ölçme ve değerlendirme boyutu ise öğrencilerin ve ailelerinin öz-sorumluluklarına bırakılmıştır. Özellikle bire-bir eğitim gerektiren orta ve ağır düzeyde OSB olan gruplar için eğitim büyük oranda ailenin sorumluluğuna kalmıştır.

Aniden geçilen uzaktan eğitim uygulamalarına olan yabancılık, öğrencilere destek olma kaygısı, özel özel eğitim kurumlarında çalışan öğretmenler/uzmanlar için işsiz kalma olasılığı, maddi kaygılar ve salgının kendi yaşamlarında ortaya çıkardığı sosyal ve psikolojik güçlüklerle baş etmek öğretmenler/uzmanlar için bu süreci oldukça stresli ve yorucu bir hale getirmiştir. Bazı öğretmenler/uzmanlar sanal ortamda, iletişim teknolojilerinin de kolay erişilebilir olması ile okulların açık olduğu zamana göre çok daha yoğun bir mesai, talep ve beklentilerle baş etmek zorunda kalmıştır. Teknolojik araçları aktif kullanan öğretmenler/uzmanlar bile, uzaktan eğitim süreçlerini yürütmeye çalışırken oldukça zorlandıklarını ifade etmişlerdir.

Aileler de uzaktan eğitimde sorumluluk almada zorlanmalarının yanı sıra mobil araçların daha önce öğrenmeye teşebbüs etmedikleri pek çok özelliğini kullanır hale gelerek kendilerini geliştirdiklerini ifade etmişlerdir. OSB olan öğrenciler ise uzaktan eğitim sürecinde TV, akıllı telefon, tablet ve ekrana alışık olmalarına karşın aileler özellikle senkron görüşme ve derslerde öğretmenlerini ya da arkadaşlarını ekranda görme durumunu yadırgayarak ekran başından kaçarken zaman içinde buna alıştıklarını ve öğretmenlerin ekrandaki canlı derslerini takip ettiklerini belirtmişlerdir. Özel eğitim ders içerikleri tüm OSB olan öğrencilerin benzer bilişsel özelliklere sahip olduğu düşünülerek hazırlanmıştır. "Özelim Özel Eğitimdeyim" ve "İçimdeki Hazine" gibi mobil uygulamalardan hangilerinin OSB olan öğrenciler için uygun olduğuna karar verme, ailelerin içerikleri nasıl kullanabileceklerine ilişsin aileleri yönlendirme ve ailelere danışmanlık yapılması gibi gereksinimler ailelerin bireysel çabalarına bırakılmıştır. Ayrıca internete ve/veya teknolojik cihazlara erişimin kırsal kesimlerde sınırlı olması nedeniyle herkese aynı kalitede erişilebilirlik sağlamak mümkün olmamıştır.

\section{Psiko-sosyal Destekte Yansimalar}

OSB olan öğrenciler ve ailelerin yaşamış oldukları ortak stres ve kaygıların başında aile rutinlerinin bozulması ve yeni rutin oluşturmada yaşanan güçlükler, öğrencilerin öğrendikleri becerileri unutması, sosyalleşme çabalarının ortadan kalkması, davranış problemleri, öfke nöbetleri ve stereotiplerin artması, uyku ve yeme bozukluğu ön plana çıkmıştır. Ayrıca TV, tablet, telefona bağımlılık; uzman yönlendirmesine duyulan ihtiyacın artması ve COVID-19 nedeniyle ölüm gerçekleşmesi durumunda "Çocuğuma ne olacak?" kaygısı yaşanmıştır. Dahası OSB olan öğrencilerin sosyalleşmeleri için çaba gösteren ailelerin salgın döneminde evde kalmanın gerekliliğini anlatmak zorunda kalmaları, ikilemler yaşamalarına neden olmuştur. Salgın sürecinde ağır düzeyde OSB'den etkilenmiş öğrencilere ilişkin bilgi bulunmamaktadır ancak OSB'den ağır düzeyde etkilenmiş çocuk ve yetişkinlerin özellikle rutinlerinin değişmesi nedeniyle öfke nöbetlerinin artması, sosyal medya üzerindeki aile destek gruplarında sıkça paylaşılan bir konu olarak karşımıza çıkmaktadır.

Türkiye'de OSB olan çocuklar için sınırlı sayıda bakım evinin bulunması, "Bizden sonra çocuğumuz ne olacak?" kaygısını yaşayan ailelerin kaygı düzeyini daha da artırmıştır. Yaşanan karantina sürecinde salgın öncesi OSB olan öğrencilerin yaşadıkları dışlanma, izole olma duygusunu şu anda salgın sürecinde herkesin eve kapanması durumuyla özdeşleştirmiş ve insanların empati yapmalarını sağlamak üzere sosyal medya aracılığıyla farkındalık çağrılarında bulunulmuştur (\#BizHepEvdeyiz, \#HerkesAynıOlsa). Bu farkındalık çağrıları ve STK örgütlerinin çabalarıyla, Türkiye'de sokağa çıkma yasağı sürerken OSB olan çocuklara günde birkaç saat dışarıya çıkma izni verilmiştir (İçişleri Bakanlığı, 2020). Aileler her firsatta hükümetten beklentilerini ve hazırlanmış olan ulusal otizm eylem planının aciliyetle ve önemle hayata geçirilmesini talep etmişlerdir. Okulların kapanmasıyla ebeveynlerin çocuklarının gelişimi ile ilgili kaygılarının artması, öğretmenlerden daha çok ilgi beklentisine dönüşmüştür. 
Herkesin evde olduğu karantina günleri, aile bireylerinin sorumluluklarının daha da artmasına neden olmuştur. Bu süreçte özellikle anneler, yoğun bir ev kadınlığının yanı sıra özel eğitim öğretmeni, oyun arkadaşı, terapist, uygun rol-model olma ve anne-babalık yapma gibi farklı roller üstlenmişlerdir. Hatta bazı STK temsilcisi ya da yöneticisi olan anneler bu görevlerinin yanı sıra ayrıca sosyal medya üzerinden canlı söyleşiler düzenleyerek ortak sorun yaşayan diğer ailelere bilgi ve psiko-sosyal destek sağlama görevi de üstlenmişlerdir. Artan sorumlulukların yanı sıra kısıtlama sürecini aile içi ilişkiler bağlamında fırsata dönüştüren aileler de söz konusudur. Yeni rutin oluşturma ve etkinlik planlama gibi süreçlerde tüm aile bireylerinin katkı sağladığı, özellikle salgın öncesinde OSB olan çocuklarının eğitim sürecinin daha çok dışında olan babaların, evdeki etkinliklere katılması ve çocuğuyla nitelikli zaman geçirmeye istekli olmaları aile içi ilişkilere olumlu bir katkı olarak değerlendirilmiştir. İnceleme ve gözlemler, ailelerin pek çoğunun sorunlarını sosyal medya üzerinden aktarmak yoluyla destek alma çabalarının en önemli baş etme stratejilerinden biri olduğunu göstermektedir. $\mathrm{Bu}$ platformlarda sorunlarının yanı sıra devletten, uzmanlardan, öğretmenlerden ve eşlerinden beklentilerini de sıkça dile getirmiş oldukları dikkat çekmektedir.

Bu süreçte öncü kurumlar (ör. MEB, Tohum Otizm Vakfi) telefonla ve e-posta yoluyla rehberlik hizmeti sunarak, eve etkinlik ve materyal göndererek ailelerin yanında olmuştur. Ek olarak OSB olan çocuk ailelerinin ya da ilgili kurumların sosyal medyada oluşturdukları destek grupları aracılığıyla, aileler sorunlarını yazıp uzmanlardan ve diğer ailelerden yanıtlar almaya çalışmışlardır. Bazıları bu sayfalar üzerinden düzenli canlı söyleşiler, röportajlar, uzman seminerleri, aile eğitimleri ve psiko-sosyal destek çalışmaları yürütmüşlerdir. STK'lar EBA'ya özel eğitim içeriği eklenmesine, OSB olan bireylerin sokağa çıkma kısıtlamasından muaf olmalarına ve özel gereksinim kapsamındaki öğrencilerin sınıf tekrarı yapması kararının alınmasına öncülük etmişlerdir. Salgını anlama, maske takma, sosyal mesafe ve evde rutin oluşturma, kanıt temelli öğretim yöntemleri, davranış yönetimi ve gelişimi destekleme gibi öncelikli konularda ailelere destek sağlamışlardır.

\section{Çıkarılan Dersler}

Uzaktan eğitim sürecinde OSB olan öğrenciler için sınıf geçmeden, ölçme ve değerlendirmeden çok daha önemli sorunlar söz konusudur. En önemlisi, OSB olan öğrencilerin okula uyum ve öğrenme motivasyonlarında yaşanabilecek düşüştür. Bu durumu engellemek üzere OSB olan öğrenciler ve aileleri için çocuklarının eğitimleri konusunda uzaktan destek sistemleri ivedilikle planlanmalıdır. Pek çok öğretmen/uzman öğretim yapmak veya öğrencilerine destek olmak amacıyla uzaktan eğitim araçlarını ve uygulamalarını daha önce hiç kullanmamışlardır. Özellikle uygulamanın ölçme ve değerlendirme kısmını bireysel çabalarla yürütmüşlerdir. Uzaktan eğitim sürecinde ölçme ve değerlendirmede sistematik bir çalışmaya rastlanmamış olsa da bu uygulamalar salgın sonrası geliştirilmeye ve güncellenmeye açıktır. Türkiye'de ilgili tüm paydaşlar için dijital bölünme konusunda yeterince etkili politikalar geliştirilememiştir. Dijital okuryazarlık becerilerine ilişkin yeterlilik konusunun acil durum politikalarında öncelikli konular arasında yer alması gerekmektedir.

\section{Durum 2: Zihin Yetersizliği}

\section{Uzaktan Ĕ̆itimde Yansımalar}

EBA platformunda zihin yetersizliği olan öğrenci ve ailelerine yönelik "Zihinsel Yetersizlik ve Kaynaştırma" ve "Zihinsel Yetersizlik ve Eğitim Planı" adlı ayrı bölümlerin oluşturulduğu görülmektedir. Bu bölümlerde hafif-orta-ağır derecede zihin yetersizliği olarak değil, sınıf düzeylerine göre bir kategoriye gidildiği ve bu kategorilere daha çok büyük yaş gruplarına kavram ve beceri öğretimine odaklanan akademik derslerle ilgili pek çok konu anlatımının ve uygulamalı etkinlik videolarının gömüldüğü gözlemlenmiştir. Sınıf düzeylerinde ise, erken çocukluk/okul öncesi yaş grubuna yönelik sınırlı sayıda materyale yer verildiği dikkat çekmektedir. Ayrıca yaşanan sorunlar arasında zihin yetersizliği olan öğrenciler için hazırlanan bazı etkinliklerdeki yönerge ve video çekim açılarının net olmaması, etkinliklerin süresinin uzun olması, genellikle düz anlatım tekniğinin kullanıldığı bazı konu anlatımlarının soyut kalması, uzman danışmanlığının yer almaması, alt yapıdan dolayı video ve görsellerin açılmasının zaman alması gibi durumlar olduğu söylenebilmektedir.

İçerisinde zihin yetersizliği olan öğrenci ve ailelerine yönelik daha çok etkinlik ve oyun temelli eğitim materyallerin yer aldığı mobil uygulamalar; MEB'in geliştirdiği "Özelim Özel Eğitimdeyim" ve MEB'in TURKCELL operatörüyle kurduğu iş birliğiyle "Engel Tanımayanlar" kampanyası altında geliştirilen "İçimdeki Hazine"dir. Ücretsiz erişim sağlanan bu uygulamalarda gelişimsel ve uygulamalı davranış analizine dayalı etkileşimli etkinlikler ve oyunlar yer almaktadır. Uygulamalar her geçen gün yeni etkinliklerin eklenmesiyle güncellenmektedir. Çocukların zihinsel gelişimiyle uyumlu bu portallarda dikkat dağıtıcı hiçbir unsur bulunmamaktadır. Kullanıı yorumlarında; ebeveynler çocukları için günlük kullanım limiti belirlediklerinde 
programın faydalı olduğunu ve telefondan sorunsuz çalıştı̆̆ını ancak programı tablete yüklediklerinde çalıştırmada sorunlar yaşadıklarını ifade etmişlerdir.

MEB tarafından planlanan "Özel Eğitim Buluşmalarında" ise, zihin yetersizliği olan öğrencilerin ailelerine ve öğretmenlerine alan uzmanları tarafından davranış yönetimi, ağır ve çoklu yetersizlikten etkilenmiş öğrencilerin eğitimi, nitelikli etkileşim ve gelişim gibi konularda uzaktan eğitimler verilmiştir. "Özel Çocuklarımızla Eğlenceli Etkinlikler Takvimi” uygulamasında ise, ailelere çocuklarıyla gerçekleștirebilmeleri için günlük olarak sunulan sanat, günlük yaşam, müzik vb. etkinlikler görsel kartlarla desteklenmiştir. Etkinliklerin uygulama videolarının olmaması ise, yetersizlikten hafif düzeyde etkilenmemiş zihin yetersizliği olan öğrenciler için zorlayıcı olmuştur.

MEB'in planladığı ve özellikle bütünleştirme/kapsayıcı eğitimdeki zihin yetersizliği olan öğrencilere yönelik diğer uygulamalar; "Ses Temelli Okuyorum Yazıyorum Okuma-Yazma Kitap Seti”, kitap, etkinlik kartları ve görsel-işitsel materyallerin bulunduğu CD'den oluşan "Eğlenmece Öğrenmece Kutusu Eğitim Materyalleri", akademik derslere yardımcı kaynak teşkil etmesi amacıyla müfredatta yer alan kazanımların etkinliklerini içeren "Uyarlanmış Etkinlikler (UYET) Kitapları", tüm dijital platformlarda yayımlanan kültür ve spor etkinliklerini içeren "Hazır Mısın?" oyunlarıdır. "Yoğunlaştırılmış Davranış Sağaltım Formatörlük Programı Eğitimi”" ve "Kapsayıcı Eğitimde Öğretmenin Yol Haritası Kitabı" ise öğretmenlerin öğrencilerinin salgın sürecinde artan davranış problemleriyle baş etmelerini ve öğretim yöntem-tekniklerinde yapılabilecek uyarlamaları destekleyen programlardır. Okulların açıldığı dönemin ilk bir ayı için oluşturulan "Telafi Eğitim Programı Çerçeve Planları" ve öğrencilerin tatil dönemini verimli geçirmesi amacıyla hazırlanan "Çerçeve Yaz Tatili Programı" ise MEB tarafindan yapılan diğer çalışmalardandır.

Salgın sürecinde MEB'e ek olarak, ülkemizdeki çeşitli sivil toplum kuruluşlarına ait çalışmalar da hız kazanmıştır. İlgili dernekler zihin yetersizliği olan öğrencilere ve ailelerine yönelik haftalık bir program dâhilinde uzaktan eğitimler düzenlemiştir. Buna ek olarak, ülkemizdeki özel özel eğitim ve rehabilitasyon merkezleri ve diğer kurumlarda çalışan öğretmenlerin/uzmanların telefon görüşmeleri ya da WhatsApp yoluyla zihin yetersizliği olan çocuk ailelerini güncel eğitimler hakkında bilgilendirdikleri ve çocukların gelişim düzeylerine uygun eğitim materyalleri paylaştıkları görülmüştür. Ayrıca çeşitli üniversitelerdeki uzmanlar tarafından zihin yetersizliği olan öğrencilerin ailelerine yönelik Instagram ve Facebook canlı yayınlarının yapıldığı; Zoom, BigBlueButton, Acaport gibi çevrimiçi platformlar üzerinden çeşitli eğitimlerin düzenlenerek etkinlik örneklerinin paylaşıldığ gözlenmiştir.

MEB tarafindan yürütülen uzaktan eğitimin değerlendirme süreciyle ilgili olarak ise; zihin yetersizliği olan öğrencilerle çalışan okul öncesi öğretmenlerinin yaptıkları yüz yüze eğitimlerdeki gözlemlerini ve salgın sürecindeki aile katılımını raporlarına yansıtabilecekleri, sene sonu belgelerini elektronik ortamda velilerin erişimine açacakları karara bağlanmıştır. Öğretmenler, bu sürece aktif olarak katılmayan ailelerin de olduğunu, böyle bir durumda ilk dönemde gerçekleştirilen öğrenci performanslarını dikkate aldıklarını dile getirmişlerdir.

Genel çerçevede, uzaktan eğitimde öğretmenlerin ve diğer uzmanların bütün imkânlarını işe koşarak olabildiği kadar zihin yetersizliği olan öğrencilere ve ailelerine ulaşmaya çalıştıkları gözlemlenmiştir. Görüşlerin paylaşıldığı platformlarda öğretmen ve aileler gerek MEB gerekse diğer kurumlar tarafindan geliştirilen uzaktan eğitim materyallerinden yoğunlukla yararlandıklarını ve ülkenin bu süreçteki politikasından memnun olduklarını dile getirmiş, ancak öğrencilerin gelişim düzeylerine uygun materyaller bulamadıklarında bireysel çabalarını (ör. internetten araştırma yapma, etkinlik kitaplarındaki etkinlikleri uyarlama, uzman eğitimlerine katılma vb.) işe koştuklarını belirtmişlerdir.

\section{Psiko-sosyal Destekte Yansimalar}

Salgın sürecinde okul çağı çocukların günlük okul rutinlerinin bozulması, akranlarından ayrılması, eve kapanması, her gün masa başı etkinlikler ya da canlı dersleri takip etmede zorlanmaları zihin yetersizliği olan öğrencilerin davranış problemlerinin artmasına neden olmuştur. İşe devam eden yetişkinlerin ise, işyerlerinin kapanması eve uyumu zorlaştırmış ve yaşanan bu belirsizlik onları boşluğa düşürmüştür. Hayatlarında ilk kez bu kadar uzun süre ev ortamında vakit geçirmenin sonucunda içe kapanma, depresyon, sürekli uyuma hali, bilgisayar, cep telefonu, tablet gibi teknolojik araçlara bağlanma gibi davranışlar göstermeye başlamışlardır. Bu süreçte en büyük stres kaynağı akran etkileşiminden yoksun olma ve eve kapanmaya bağlı gelişen yoğun yalnızlık duygusu olmuştur. Ebeveynler ise işten ayrılmanın getirdiği ekonomik sorunların yanı sıra, özellikle 0-3 yaş döneminde tanı değerlendirme sürecinin durması nedeniyle rehberlik hizmetlerine erişemedikleri için kendilerini çaresiz hissederek destek arayışına girmişlerdir. Evde kalma sürecinde çocuklarıyla akademik ve sosyal gelişimi 
destekleyici etkinlikleri nasıl planlayacakları, artan davranış problemleriyle nasıl baş edecekleri konusunda büyük endişeler de yaşamışlardır. Bu endişeler ise, hane içi iletişimde sorunlara yol açarak aile iklimini bozmuştur. Öte yandan ailelerin bu süreçte yoğun öğretim odaklı olmaktan ziyade, evdeki mutlu atmosfer ve çocuklarının sağlık, bakım ve mutluluğuna odaklandıkları; çocuklarının gelişimlerine yönelik ise eğitim desteğine ihtiyaç duydukları dikkat çekmiştir.

Salgın sürecinde MEB e-rehberlik sistemini ve Özel Eğitim ve Rehberlik Hizmetleri Bilgilendirme Hattını, Aile, Çalışma ve Sosyal Hizmetler Bakanlığı (AÇSB) ise telefonla destek hizmetini işe koşmuştur. Bu süreçte zihin yetersizliğiyle ilgili en kapsamlı çalışmalardan biri Türkiye Down Sendromu Derneği'nin gençlere yönelik gerçekleştirdikleri serbest zamanı değerlendirme, eğlence, yiyecek hazırlama, yoga, spor ve sanat etkinlikleri, gençlerle 4 çayı gibi etkinlikler ile ailelere yönelik gerçekleştirdikleri aile içi iliş̧kileri konu alan düzenli Facebook canlı yayınları olmuştur. Ayrıca dernek Dünya Sağlık Örgütünün stresle başa çıkma rehberini (Stresli Zamanlarda Önemli Olanı Yapmak) çevirerek yayımlamış ve psikolojiyi korumakla ilgili uzman yazıları paylaşmıştır. Yine Zihinsel Yetersiz Çocukları Yetiştirme ve Koruma Vakfi (ZICÇEV) da salgın sürecine özel çevrimiçi eğitim platformundan sosyal desteklere yer vermiştir. Bunların yanı sıra, özel özel eğitim ve rehabilitasyon merkezleri, danışmanlık merkezleri, dernekler, vakıflar ve diğer özel kurumları Facebook, Instagram, Twitter hesaplarında ve kendi web sitelerinde eğitsel/psiko-sosyal destek sunduğu canlı yayınlar düzenlenmiş, çevrimiçi iletişim platformları (ör. Skype, Zoom, Acaport vb.) aracıllığılla web seminerleri ve sohbetler gerçekleştirmişlerdir.

\section{Çıkarılan Dersler}

Geliştirilen uzaktan eğitim platformlarında içerik sunmada materyal çeşitliliğine önem verilse de özellikle küçük yaş gruplarına yönelik içeriklerin zenginleştirilmesine ihtiyaç vardır. Ölçme ve değerlendirmelerin ise daha çok birinci dönemdeki notlara, esnek bakış açısına ve çoğunlukla bireysel çabalara dayalı bir sistemle gerçekleştirildiği söylenebilmektedir. Çoğu uygulamanın kapsamlı, erişilebilir, güncellenebilir bir yapıda tasarlanmış olması salgından sonra da kullanabilirliği artıracaktır. Bunun yanı sıra, etkileşimli materyallere erişim için altyapı sorunlarının çözüme kavuşturulmasının ve kullanma kılavuzlarının hazırlanmasının yaygın etkiyi artırabileceği düşünülmektedir. Dahası bazı uygulamaların içeriğinde OSB olan öğrencilere, özel yetenekli ögrencilere ilişskin alt bölümler gibi zihin yetersizliği olan öğrenciler ve aileler için de özelleştirilmiş bir bölüm mutlaka geliştirilmelidir. Psiko-sosyal bağlamda ise, resmî kurumların sundukları hizmetler kapsamlı ve etkin olduğu kadar, her aile için erişilebilir olamamıștır. Aynı zamanda destek sürecinin uzaktan yürütülmesi ve hedef kitlelerin büyüklüğü, zaman, maliyet gibi sınırlılıklar rehberlik desteklerinin her vatandaş bazında sistematik bir programla sunulmasını güçleştirmiştir. Bu süreçte zihin yetersizliği ile ilgili daha çok sayıda sivil toplum kuruluşunun aktif olması ve iş birliğinde bulunmasının ne denli gerekli olduğu açıkça ortadadır.

\section{Durum 3: İşitme Yetersizliği}

\section{Uzaktan Ĕ̈itimde Yansımalar}

EBA içeriğinin işitme yetersizliği olan bireyler için yetersiz kaldığı gözlemlenmiştir. Bu düşüncenin oluşmasının sebebi derslerin anlatımında alt yazının ve işaret diline dayalı bir anlatımın olmamasından kaynaklı işitme yetersizliği olan öğrenciler açısından sorunların yaşanmış olduğudur. Bu durum özellikle EBA üzerinden MEB'e bağlı özel eğitim (yatılı ve gündüzlü) okullarında eğitim alan öğrenciler için söz konusudur. EBA ile birlikte öğretmenlerin ayrıca Zoom, Skype ve WhatsApp gibi çeşitli dijital platformlar kullandıkları ortaya çıkmıştır. Öğretmenler bu platformlarda canlı dersler gerçekleștirmiş, konu anlatımlı videolar çekip öğrencilerine göndermiş ya da öğrencileriyle çeşitli içerikler ve etkinlikler paylaşmışlardır. Bu tür uygulamalarda öğretmenlerin genel olarak doğrudan öğrenciye ulaşmak yerine aileler ile iletişime geçerek öğrencilere dolaylı eğitim hizmeti sundukları ortaya çıkmıştır. Diğer yandan özel eğitim okullarında hizmet veren öğretmenler ve aileler büyük oranda teknoloji kullanımında, internet erişimlerinde sorunlar yaşamışlardır. Bu nedenle aileler tarafından bu sürecin çok da nitelikli yürütülememiş olduğu gözlenmiştir. Öğretmenlerin ise etkinlik ve içerik üretmede kendilerini yetersiz hissettikleri görülmüsstür.

Uzaktan eğitim sürecinde kapsayıcı eğitim ortamında özellikle dil ve iletişim becerilerinde gereksinimleri olan işitme yetersizliği olan öğrencilere eğitim veren öğretmenlerin Zoom üzerinden yürüttükleri canlı derslerin çok hızlı ilerlediğine ilişkin aile paylaşımlarının olduğu dikkat çekmiş̧ir. Bu nedenle öğrencilerin ders içeriklerini takip etmekte zorlandıkları söylenebilmektedir. Dolayısıyla öğretim materyallerinin ve öğretimsel tasarımının işitme yetersizliği olan öğrencilerin bireysel gereksinimlerini karşılamada yetersiz kaldığı görülmüştür. 
Özel Özel Eğitim ve Rehabilitasyon Merkezleri kendilerinden destek alan işitme yetersizliği olan öğrencilerle genellikle Skype üzerinden canlı bağlantılar kurmuşlardır. Bu kapsamda aileler çok istekli olmamış, istekli olanlar ise dil ve iletişim becerilerinden çok akademik becerilere yönelik etkinlikler talep etmişlerdir. Salgın süreci uzadıkça katılımcı aile sayısının oldukça azaldığı ortaya çıkmışıır. Bu noktada yapılan bütün uygulamaların yürütülmesinde kurumların, öğretmenlerin ve ailelerin inisiyatifinin, bakış açısının ve tutumunun ön planda olduğu sonucuna varılmıştır. Öğretmenlerin ve ailelerin dijital yeterliliği, kısıtlama sürecindeki psikolojik durumları, öğretmenlerle kurumların mesleki tutumları ve eğitime bakış açıları, uzaktan eğitim içeriğinin yeterliliği, ailelerin sosyo-ekonomik durumları, çalışma durumları gibi birçok faktör uzaktan eğitimde rol oynayan kişilerin tepkilerinde olumlu ya da olumsuz etkiler doğurmuştur. Kısacası uzaktan eğitimde önemli rol oynayan öğretmen/uzman, aile ve öğrenci tepkileri ile uzaktan eğitimin olumlu ve olumsuz yönleri bireysellik göstermiş̧tir. Bazıları uzaktan eğitim sürecine aktif katılım göstermiş, bazılarının sürecin sonlarına doğru olumlu tutumları olumsuza dönüşmüş, bazıları ise uzaktan eğitim sürecine hiç katılmamışlardır. Ailelerin katılmama nedenleri arasında büyük bir çoğunluğunun ilkokulu zor bitirmiş olmaları, konuların birçoğunu kendilerinin de anlamamaları/bilmemeleri yer almıştır.

\section{Psiko-sosyal Destekte Yansımalar}

Toplumsal yaşamda hâlihazırda dezavantajlı olan işitme yetersizliği olan öğrencilerin yetersizliklerinden kaynaklı gereksinimlerine bir de salgın sürecinde ortaya çıkan gereksinimler eklenince bu öğrencilerin ve ailelerinin günlük yaşamlarını sürdürme, yaşamsal gereksinimlerini karşılama gibi konularda stres, kaygı ve endişe yaşama olasılıklarının arttığı gözlenmişstir. Özellikle işitme yetersizliği olan öğrenciler için uzaktan eğitim sürecinde yaşanan sorunlar ve eksiklikler bu öğrencilerin eğitim süreçlerinde ailelerine daha da bağımlı kalmalarına ve ailelerin de yeni roller üstlenmelerine neden olmuştur. Çocuklarının gün boyu okulda zaman geçirmelerine alışmış ve ilk kez böylesine tam zamanlı eğitici role sahip olan ailelerin deneyimsizliği durumu iyice zorlaştırmıştır. Öte yandan salgın sürecinde bulaşma riski aile içinde en büyük kaygı kaynağı olmuştur. İşitme yetersizliği olan öğrencilerin özellikleri gereği dil ve iletişim becerilerinin gelişimindeki gereksinimlerinin ve sosyal çevrede bulunamadıkları için sosyalleşme ihtiyaçlarının karşılanamamış olması aile içi stres ve mutsuzluk gibi sorunları artırmıştır. $\mathrm{Bu}$ açıdan bakıldığında devletin ve bazı toplulukların ailelere sağladığı psikolojik hizmetler, aile eğitimleri ve terapileri yol gösterici olabilmiştir.

Kısıtlama sürecinde kamu kurumları, belediyeler, STK ve bazı özel topluluklar da işitme yetersizliği olan öğrencilere yönelik salgın sürecinin olumsuz etkilerini en aza indirecek, evde alternatif yaşam sunabilecek konularda destek hizmet sağlamaktadırlar. Örneğin; Sağlık Bakanlığı tarafından kurulan "Gebe Okulları" uzaktan eğitim platformunda işitme yetersizliği olan anne adayları için videoları işaret diliyle de anlatarak erişilebilirliği artırmıştır. İşitme Engelliler ve Aileleri Derneği, 18 Nisan 2020 tarihinde üyelerini koronavirüs hakkında bilinçlendirmek amacıyla Zoom platformu üzerinden işaret dili ile uzaktan seminer gerçekleştirmiştir. Isparta Belediyesi ise işitme yetersizliği olan bireylerin dudak ve mimik hareketlerinin anlaşılabilmesi amacıyla ağız bölgesinin şeffaf olduğu bir maske üreterek bu bireylere dağıtmıştır.

Herkes için Spor Federasyonu HisApp uygulamasında, salgın sürecine yönelik "İsitme Engelliler İçin Spor" başlğ̆ altında işaret diliyle ve görsellerle destekli içerik güncellemesi yapılmıştır. Türkiye İşitme Engelliler Spor Federasyonunun ise bünyesindeki tüm paydaşlara yönelik çeşitli projeler yürüttükleri ve yarışmalar düzenledikleri görülmüştür. Salgın sürecinde destek topluluklarının, işitme yetersizliği olan bireylerin yaşadıkları sorunların çözümüne yönelik farkındalık oluşturma ve talep etme gibi rolleri de bulunmaktadır. İşitme Engelliler ve Aileleri Derneğinin, salgın sürecinde işitme yetersizliği olan bireylerin ülke gündeminden haberdar olmaları için Cumhurbaşkanının ulusa sesleniş konuşmasında işaret dili ve alt yazı talebinde bulunması buna örnek olarak gösterilebilir. Şimdiye kadar bahsedilen faaliyetlerin WhatsApp, Instagram, Facebook grupları gibi sosyal medya toplulukları, varsa toplulukların internet siteleri ya da resmi sosyal medya hesapları üzerinden duyurularak iletişim sağlandığı görülmüştür.

\section{Çıkarılan Dersler}

Ulaşılan bu sonuçlar salgın sürecinde işitme yetersizliği olan öğrencilere uzaktan eğitime erişim, eğitimin niteliği ve sürdürülebilirliği üzerine yapılacak sorgulamaların göstergeleri olabilir. Bu süreçte EBA üzerinden yürütülen derslerin uzaktan eğitim anlamında iyi işlediği ancak işitme yetersizliği olan öğrencilere yönelik içerikleri somutlaştırma ile görsel materyal, alt yazı, işaret dili ve öğretimsel uyarlamaların uzaktan eğitimin içeriğine de yansıtılması gerekliliği ortaya çıkmıştır. İşitme yetersizliği olan öğrencilere yönelik eğitim, günlük yaşam, sosyal yaşam gibi bütün alanlarda insan hakları, evrensel tasarım, erişilebilirlik, tam katılım, firsat eşitliği gibi ilkelerin de dikkate alınması gerekmektedir. Sözü edilen ilkelerin eğitim hayatına yansıması için atmamız 
gereken çok adım olduğu çıkarımı yapılırken eğitime oranla işitme yetersizliği olan bireyler için spor egzersizleri, gebelik, şeffaf maske üretimi ve dağıtımı gibi psiko-sosyal bağlamda daha somut adımlar atıldığı yorumu yapılabilir. En önemlisi işitme yetersizliği olan öğrencilerin uzaktan eğitim sürecinin öğretmenlerin, ailelerin ve kurumların inisiyatifine bırakılmış olmasının uzaktan eğitimde keyfi ve adaletsiz uygulamalara neden olabileceği düşüncesini akla getirmektedir. Bu sorunun önüne geçebilmek adına uzaktan eğitim uygulamalarının denetimli bir sisteme tabi tutulması öncelikli planlanması gereken konular arasında olmalıdır.

\section{Durum 4: Görme Yetersizliği}

\section{Uzaktan Eğitimde Yansımalar}

Uzaktan eğitim sürecinde görme yetersizliği olan öğrenciler için ders anlatımlarında betimlemelerin az olması veya hiç olmaması, incelenmesi istenen resmin/fotoğrafın (görselin) çok kısa süre ekranda kalması, okunan soruların tamamının değil sadece soru köklerinin okunması gibi durumlardan kaynaklı olarak görme yetersizliği olan öğrenciler daha fazla süreye ihtiyaç duymuşlardır. Buna ek olarak az gören öğrenciler ekranda yer alan görselleri görebilmek için telefon ile ekranın fotoğrafını çekip daha sonra telefondan büyüterek incelemek durumunda kalmışlar ancak bazı görseller çok kısa ekranda kaldığı için bu da mümkün olmamıştır. EBA TV üzerinden yapılan anlatımlarda bu tip problemler yaşanırken EBA uygulamasında da erişilebilirlikle ilgili sorunlar gözlemlenmiştir. Az gören öğrencilerin uygulama içinde yer alan yazıların puntolarının yeterli büyüklükte olmaması, görsellerde netlik ve kontrastın yeterli olmaması gibi sorunlardan dolayı görmekte zorlandıkları görülmüştür. Bu tür problemlere rağmen özellikle az gören öğrenciler, EBA uygulamasının kendileri için konu açıklıklarını kapatabildikleri ve dersleri toparlayabildikleri önemli bir uygulama olduğunu da belirtmiş̧lerdir. Hiç görmeyen öğrenciler ise az gören öğrencilere oranla daha dezavantajlı grupta yer almaktadır. Bu öğrenciler için anlatılan derslerdeki tahtaya yazılan, görseli gösterilen her şeyin betimlenmesi gerekmektedir.

Aileler çocukları ile dersleri izleyerek görseller ile ilgili betimlemeleri yapmaya çalışmışlardır. Ne var ki bu her aile için mümkün olamamış ve öğrencinin anlatılanları kaçırmasına, odaklanamamasına neden olmuştur. Özellikle sayısal derslerdeki şekilli sorular ile İngilizce dersi bu öğrencilerin en çok güçlük yaşadıkları dersler olarak görülmüştür. İngilizcenin yazılışının okunuşundan farklı olmasından dolayı sözcükler harf harf aktarılmadığı zaman anlaşılmasının güç olduğu gözlemlenmiştir. Yine görmeyen ve Braille okur-yazarı olan öğrenciler için Braille öğretim içeriklerinin bulunmaması ilkokul düzeyindeki öğrenciler için önemli bir eksiklik olarak görülmektedir. EBA TV ve uygulamasının yanı sıra öğretmenler de bu süreçte öğrencilere daha çok destek olabilmek ve eksikliklerini giderebilmek adına farklı uygulamalar üzerinden de canlı dersler yapmaya başlamışlardır. Öğrenciler özellikle canlı derslerden daha fazla yararlanmışlardır. Öğretmenlerin öğrencilerinin gereksinimlerini bilmesi, konuları anlayacakları şekilde sunması, onların eksiklerini gidermek açısından önemli olmuştur. Görmeyen öğrenciler ile çalışan bu öğretmenler öğrencilerinin yaptıklarını kontrol etmekte sıkıntı yaşamalarından özellikle matematik derslerinde küptaş ile yapılan çözümlerin yavaş ve kontrolünün zor olmasından kaynaklı olarak daha çok ezbere dayalı, zihinden hesaplama yoluyla matematik işlemeye çalışmışlardır. Yine okuma yazmaya ağırlık vererek Braille yazma kuralları ve Braille okumaya yönelik alıştırmalar yapmışlardır. Ancak internete ulaşamayan veya farklı uygulamaları kullanmakta problemler yaşayan aileler sadece televizyon üzerinden verilen yayınlar ile bu süreci geçirmişlerdir. Aileler ve öğrenciler bu kaygıları hissederken uzaktan verilen eğitimde tam anlamıyla ölçme-değerlendirme ve dönüt düzeltmelerin yapılamaması da öğrencilerin ulaştıkları seviyeyi görmeyi engellemektedir. Öğrenciler ve aileleri daha çok kendi kendilerini değerlendirmek durumunda kalmışlardır.

\section{Psiko-sosyal Destekte Yansimalar}

Görme yetersizliğinden etkilenmiş öğrencilerin ve ailelerinin yaşadıkları sorunlar; gören akranlarından geri kalma korkusu, öğretmen rolü üstlenmenin yarattığı yorgunluk, evde kalmaktan dolayı çocukların sıkılması ve bunun olumsuz etkilerinin aile ortamına yansıması olarak sayılabilir. Bu sorunlardan ilki ve en büyüğü, görmeyen öğrencilerin ailelerinin, müfredatta yer alan konularda kendi çocuklarının geri kalmasından dolayı yaşadıkları endişedir. Öğrencilerin az gören ya da görmeyen, görme engelliler okullarına ya da kaynaştırma/bütünleştirme yoluyla eğitim ortamına devam ediyor olması fark etmeksizin, aileler bu endişeyi yaşamaktadırlar. Kaynaştırma/bütünleştirme yoluyla eğitim ortamına devam eden öğrencilerin aileleri belki biraz daha fazla endişelidirler çünkü bu eğitim ortamlarında öğrencinin sınıfındaki gören akranlarından bilgi ve beceri anlamında kopmaması gerekmektedir. Oysa görememek yüz yüze eğitimde bile bir dezavantaj iken uzaktan eğitimde daha büyük sorunlara yol açmıştır. Çocuklarının sınıf düzeyinden geri kalacağından endişelenen aileler, özellikle de anneler, çocuklarına bir öğretmen gibi uzaktan eğitimin açıklarını kapatacak şekilde eğitim vermeye, dokunsal materyaller hazırlamaya çalışmışlardır. Bu da özellikle annelerde yorgunluğa neden olmuştur. Bazı 
annelerin iki ya da daha fazla çocuğunun olması ve diğer çocuklarının da ilgi beklemesi bu yorgunluğu anlamaya hizmet edecektir. Lise dönemindeki öğrencilerin aileleri ise bu döneme ait konuları anlamadıkları için çocuklarına da yardım edememiş, bu durum onların endişelerini daha da artırmıştır.

Sosyal anlamda çocukların arkadaşlarını ve okulu özlemelerinin de yaşanan ikincil bir sorun olduğu gözlenmektedir. İlkokul ya da ortaokul dönemindeki öğrencilerin aileleri çocuklarına farklı etkinlikler bulmaya çalışırken, lise döneminde olan öğrencilerin aileleri ise ergenliğin de etkisiyle aile içi ergen çatışmaları yaşamışlardır. Tüm bu zorluklara ve yaşanan endişelere rağmen aileler ve çocukları için evde birlikte kalmanın olumlu yönlerinin de olduğu görülmektedir. Aileler kadar öğrenciler de salgın sürecinden farklı şekillerde etkilenmişlerdir. Özellikle yaşça büyük olan öğrenciler okula gitmek yerine evde olmaktan, devamsızlık sorunun olmamasından, ders sürelerinin kısa olmasından memnun kalmışlardır. Ancak öğretmene soru soramamaları, dönüt alamamaları ve dersi dinlemek için TV başına geçmekte motivasyon eksikliği yaşamaları olumsuz bir durum olarak görülmektedir.

Görmeyen öğrenciler ve aileleri salgın döneminde sosyal destek gruplarından çok az yararlanabilmişlerdir. Ailelerde salgın sürecinde sunulan bu desteğin salgın sonrası da devam etmesi beklentisi doğmuştur. Ayrıca günlük derslerdeki sorunlarında yalnızca WhatsApp gruplarından yararlanmışlardır. Bu gruplarda, aileler ya da liseye devam eden öğrenciler karşılaştıkları sorunların çözümlerini birbirleriyle paylaşmışlardır. Yeterli olmamakla birlikte en çok desteği, görmeyen çocuğa sahip annelerin kurduğu "Dokunsal Anneler" gönüllü platformundan almışlardır ancak bu desteğin de Türkiye geneli düşünüldüğünde yetersiz olduğu görülmektedir. Bu durumda çocuğunun eğitimden çok geri kaldığı ve ilerleyen yıllarda toparlamakta zorlanacağı düşüncesi aileleri kaygıya sürüklemiş, sınıf tekrarı gibi alternatifleri düşünmelerine neden olmuştur.

\section{Çıkarılan Dersler}

Bu salgın süreci görme yetersizliği olan öğrencilere uzaktan eğitim vermeye hiç de hazır olunmadığını göstermektedir. Özellikle Braille yazının dokunsal olması, okuma yazmada ya da matematikte uzaktan video ile göstermeye ya da fotoğrafla anlatmaya olanak tanımaması büyük zorluk yaratmıştır. Ailelerin de kabartma yazı bilmemeleri çocuklarına verecekleri desteği sınırlandırmıştır. Ancak teknolojinin geliştiği bu çağda çözümleri bulmak zor da olsa olanaksız değildir. Bilgisayar klavyesini kullanarak Braille yazıyı bilgisayar ekranında yazmasını mümkün kılan programlar vardır. Bu programlar sayesinde öğretmen, paylaşılan ekranda öğrencisinin Braille yazıyı (matematikte işlemleri, sayıları vb.) doğru yazıp yazamadığını kontrol edebilir. Teknolojinin kullanımı ise ailelerin ve öğrencilerin bu teknolojiye erişimleri ile sınırlıdır. Bilgisayarı, akıllı cep telefonu ya da internet erişimi olmayan aileler olduğu da unutulmamalıdır. Ayrıca Braille okuma materyallerine erişimde ciddi bir sıkıntı vardır. Braille kitaplara öğrencilerin erişimi kolaylaştııılmalıdır. Bu kitapların çeşitlendirilmesi, gören bir öğrencinin ulaşabildiği kitap çeşitliliğinde yelpazenin genişletilmesi gerekmektedir.

\section{Durum 5: Dil ve Konuşma Bozukluğu}

\section{Uzaktan Ĕ̈itimde Yansımalar}

Kısıtlama sürecinde Dil ve Konuşma Terapistleri (DKT) terapi gören öğrencilere ve/veya ailelerine telefonla ulaşarak önceden çalışılan amaç ve materyalleri mobil uygulamalar aracilığıyla paylaşmış olsalar da terapi süreçleri sekteye uğramıştır. Dolayısıyla hastanelerde dil ve konuşma terapisi alan öğrencilerde salgın öncesinde kazandırılmış olan terapi hedeflerinde gerilemeler görülmüştür. Bir diğer eğitim ortamı olan Özel Özel Eğitim ve Rehabilitasyon Merkezleri ve Özel Dil ve Konuşma Terapisi Danışma Merkezlerinde çalışan DKT'ler, terapi süreçlerini aksatmamak amaciyla teleterapi düzenlemeye uygun olan vakalar ile Zoom ve Skype üzerinden terapilerini gerçekleştirmişlerdir. Bu süreçte danışan ile ekran paylaşımı yapılarak terapi seansları tamamlanıp bir sonraki görüşmeye kadar ailelerin veya yetişkin olan vakaların kendilerinin terapi hedeflerini pekiştirmeleri için ödevler verilmiştir. Uzun süre online terapi yapılması gereken durumlarda ailelerden destek alınarak molalar verilmiş ve öğrencilerin aileleri ile vakit geçirmeleri sağlanmıştır. DKT'ler ile birlikte etkinlik yapmaya uygun olan vakalarda ise video izleme, oyun oynama vb. şeklinde planlamalar ile terapi araları düzenlenmişsir.

Teleterapi sürecinde görüntülü konuşmaya olanak sağlayan cihazlar ailelerin olanaklarına göre değişiklik göstermiştir. Tercih edilen uzaktan teknoloji araçları genellikle bilgisayar, telefon veya tablet şeklinde olmuştur. $\mathrm{Bu}$ süreçte yüz yüze terapilerde kullanılan materyallerin dijital ortamda taranmış halleri ailelerle paylaşılmıştır. Evde terapötik amaçlı kullanılabilecek materyaller de sürece dâhil edilmiştir. Dijital yeterlikte güçlük yaşayan öğrenciler veya ailelerine, terapiyi planlayan DKT'ler tarafından Zoom kullanımı, görüntü ve ses ayarlarının yapılması gibi konularda çeşitli yönlendirmeler yapılarak destek sunulmuştur. Bu süreçte mevcut terapilerin teleterapi ile sürdürülmesinin yanında DKT'lere yeni vakalar da başvurmuştur. Teleterapi sürecinde yeni 
başvuruda bulunan vakaların terapi hedeflerinin belirlenebilmesi için vaka öyküsü alma, ailelerden bilgi toplama ve karşlıklı spontane konuşma yoluyla vaka hakkında bilgi toplama gibi informal değerlendirmeler yapılmıştır. İnformal değerlendirme bulgularını desteklemek amacıyla formal değerlendirme araçları da kullanılmıştır. Standart testlerin uygun olanları tarayıcı aracılığıyla dijital hale dönüştürülmüş ve ekran paylaşımı yapılarak vakalara sunulmuştur. Teleterapi olarak adlandırılan bu uzaktan eğitim sürecinin DKT'ler için olumlu ve olumsuz pek çok yönü ortaya çıkmıştır. Zamanı verimli kullanmayı sağlaması, mekana bağlı kalmadan terapi yapmaya olanak sağlaması, terapi süreçlerinin sekteye uğramaması ve sürdürülebilir olması, maliyetin azalması olumlu yönler arasında yer almıştır. Özellikle özel gereksinimi olan, davranış ve dikkat problemleri olan ve erken dönemde müdahale gerektiren küçük yaştaki öğrencilerle uzaktan eğitim gerçekleştirilememiştir.

Uzaktan eğitim sürecinde bireysel farklılıkların dikkate alınamaması bu süreci yönetmede güçlükler yaşanmasına neden olmuştur. Bu hizmetlerden yararlanabilecek durumda olan vakalardan bir bölümü ise bu yolla sunulan terapilerin sosyal güvenlik kapsamında olmaması nedeniyle hizmetlerden yararlanamamıştır. Öte yandan dil ve konuşma bozukluğu olan öğrencilerle yüz yüze iletişim kurulamamasından kaynaklı olarak bazı müdahale uygulamaları yetersiz olmuştur. Konuşma sesi bozuklukları terapisi gibi dudak-dil hareketlerine model olunan müdahalelerde DKT, hedef sesin modelini tam olarak görüntü üzerinden aktarıp aktaramadığı konusunda kaygı yaşamıştır. Örneğin; Prompt gibi dokunsal olarak uyaran gerektiren uygulamalarda aileden destek alınsa da müdahale etkili bir şekilde tam anlamıyla gerçekleştirilememiştir. Ailelerin isteğiyle DKT'lerin bir bölümü ise evlere giderek gerçekleştirmiş oldukları özel terapilerini sürdürmeye devam etmiştir. DKT'ler bu süreçte gerekli önlemleri almış, dudak kısmı şeffaf maskeler hazırlamış ve vaka ile karşılıklı hijyen ve sosyal mesafe kurallarına uyarak terapileri gerçekleştirmiştir. Ek olarak bu süreçte aileler belirli sırayla açılan çeşitli eğitici oyunların yanı sıra, konuşma güçlükleri yaşayan çocuklar için Alternatif ve Destekleyici İletişim Sistemi'ni (ADİS) içeren "İçimdeki Hazine" mobil uygulamasından da yararlanmışlardır. TRT EBA TV İlkokul ve Ortaokul kanallarında dil ve konuşma bozukluğu olan öğrencilerin ailelerine yönelik olarak da bilgilendirme oturumları düzenlenmiştir.

\section{Psiko-sosyal Destekte Yansimalar}

Uzun süreli eve kapanma ile birlikte akran etkileşiminden ve okuldan uzak kalma süreci dil ve konuşma bozukluğu olan öğrencilerin sosyal iletişim becerilerini ve psikolojilerini olumsuz yönde etkilemiştir. Bu durum dil ve konuşma bozukluğu olan öğrencilerin davranış problemleri göstermelerine ve teknolojik araçlarla uzun saatler geçirmelerine neden olmuştur. Ailelerde, özellikle dil ve konuşma gelişiminde kritik bir dönem olan erken çocukluk dönemini boşa geçiriyor olma düşüncesi endişe yaratmıştır. Teleterapi uygulamaları ile uzaktan eğitim sürecine katılan aileler çocuklarının terapi sürecine ilgi duyup duymayacakları ve DKT tarafından kendilerine verilen yönergeleri doğru bir şekilde yerine getirip getiremeyecekleri konusunda da endişe yaşamışlardır. $\mathrm{Bu}$ süreçte aile üyelerinin, anne-baba sorumluluklarının yanında eğitmen/terapist sorumluluğunu almak zorunda kalmaları tükenmişlik duygusu yaşamalarına neden olmuştur. Aileler karşılaş̧ıkları sorunlarla baş edebilmek için uzmanlardan ev ortamında ne gibi stratejiler uygulayabilecekleri konusunda görüntülü görüşsmelerle destek almıştır. Aynı zamanda bu süreçte uzmanlar tarafından sosyal medyanın aktif kullanılması da ailelerin yönlendirilmesini ve uygun stratejiler kullanmasını desteklemiştir. Alanda çalışan uzmanlar, bu süreçte Facebook, Instagram gibi sosyal medya üzerinden kurmuş oldukları topluluklarda bilgi alışverişinde bulunmuş, farklı konular üzerine (ör. konuşma sesi bozukluklarında teleterapi süreci) canlı yayınlar düzenleyerek tartışma grupları oluşturmuşlardır. Aileler de bu süreçte sosyal medya üzerinden dil ve konuşma bozukluklarına yönelik aile-destek toplulukları oluşturmuştur. Aileler bu gruplarda çocukları ile yaptıkları etkinlikleri ve çalışmaları paylaşmıştır.

Önemli bir STK olan Dil ve Konuşma Terapistleri Derneği (DKTD), salgın sürecinde derneğin web sitesi üzerinden uzaktan terapi sürecine ve COVID-19'a ilişkin bilgilendirmelerde bulunmuştur. Yerinde sunulan terapi hizmetlerinin mümkün olmadığı zamanlarda kullanılan teleterapi yöntemine ilişkin kılavuz niteliğinde bir broşür, derneğin web sitesinde paylaşılmıştır. Bununla birlikte derneğin web sitesinde COVID-19 olan ve yoğun bakımda konuşmakta güçlük yaşayan hastalar için hazırlanan Türkçe ve Arapça dillerine ait ADİS kartları paylaşılmıştır. DKTD tarafından, COVID-19 Pandemi Kılavuzu yayımlanmış ve DKT'lerin bu süreçte nelere dikkat etmesi gerektiğine, kişisel koruyucu ekipman kullanımına ve bu süreçte dil ve konuşma terapisi uygulamalarında yapılması gerekli olan değişiklerin neler olduğuna ilişskin bilgilendirme yapılmıştır. DKTD, yeni normalleşme sürecine hazırlık amaçlı DKT'ler, çalışan personel, vakalar ve aileleri ve ortak kullanım alanlarında hijyen kuralları ve alınması gereken önlemler için bir çalışma rehberi hazırlamıştır. Bir diğer sivil toplum kuruluşu olan Özel Eğitimciler Derneği (ÖZDER), Tohum Otizm Vakfı ve Türkiye Down Sendromu Derneği, web sayfaları üzerinden aile ve uzmanlara yönelik dil ve konuşma becerilerinin desteklenmesine ilişkin çevrimiçi eğitimler ve seminerler düzenlemiştir. Aynı zamanda üniversitelerin Dil ve Konuşma Terapisi bölümlerinde çalışan akademisyenler ve 
uzmanlar, dil ve konuşma bozukluklarına yönelik bilgilendirme videoları çekerek üniversitelerin kendi web sayfası ve Youtube üzerinden bu videoları paylaşmıştır.

\section{Çıkarılan Dersler}

Teleterapi sürecine dâhil olamayan özellikle ikinci yetersizliği iletişim, dil ve konuşma bozukluğu olan vakalarda, DKT'nin vakanın çalıştığı diğer uzmanlarla iş birliklerinin sağlanmasında zorlanılması ve çoğu zaman ise mümkün olamaması iş birliği konusunda uzman ekip sistemi gibi çalışmalara ihtiyaç olduğunu ortaya koymaktadır. Çocuklarıyla en fazla zaman geçiren kişiler olarak ailelerin sürece mutlaka katılması, bu amaçla çocuklarının iletişim ve dil becerilerini destekleyici mobil uygulamalar ve ilgili stratejileri öğrenebilecekleri platformlar (ör. herkesin erişiminin olabileceği televizyon aracıllğıyla EBA içeriklerine iletişim becerileri ekleme gibi) geliştirilmelidir. Dil ve konuşma bozukluğu olan çocuk ve yetişkinleri destekleyecek sosyal ağlar çeşitlendirilmelidir. Kısıtlama sürecinde sunulan tüm desteklerin salgın sonrasında da sürekliliği devam etmelidir. Bununla birlikte her vaka ve ailenin uzaktan eğitim sürecine katılamadığı gibi her DKT'nin de bu sürece dâhil olamadığı görülmektedir. Kısıtlama sürecinde terapileri sürdüremeyen ve tamamen sonlandıran çok sayıda DKT de bulunmaktadır. DKT'nin bireysel yatkınlığı, klinik deneyimi ve dijital yeterliliği gibi konular bu noktada dikkat çekmektedir. $\mathrm{Bu}$ açıdan bakıldığında da ülkemizde ortalama standartta teleterapi süreci ölçütlerinden ve veriminden söz etmek mümkün olamamaktadır. Sunulan terapi kalitesinde DKT’nin sadece mesleki yeterliği değil dijital yeterliği ve yatkınlığı da etkili olmaktadır.

\section{Durum 6: Dikkat Eksikliği ve Hiperaktivite Bozukluğu (DEHB)}

\section{Uzaktan Eğitimde Yansımalar}

Salgın nedeniyle eğitim öğretime bir süre ara verilmesiyle aileler ciddi biçimde bundan sonra ne olacağ kaygısı yaşamışlardır. Çocuklarının günlük eğitimini planlamakta ve uygulamakta, dikkatlerini düzenlemede, enerjilerini amaçlı hareketler yoluyla atmalarını sağlamada ciddi zorlanmalar yaşamışlardır. Hedefi doğrudan bu öğrenciler olmasa da EBA platformu aracılığıyla hazırlanan dokümanlar arasından ebeveynler çocuklarının evde yapabilecekleri aktiviteler ve çalışma kâğıtlarından yaralanmışlardır. Örneğin Özel Çocuklarımızla Eğlenceli Etkinlikler Takvimi'nden (ÖÇEET) hemen hemen her gün etkinlikler yayımlanmış ve ebeveynler çocuklarıyla yapabilecekleri bu etkinlikleri planlayarak uygulamışlardır. Ayrıca "Özelim Özel Eğitimdeyim" ve "İçimdeki Hazine" gibi ücretsiz erişim sağlanan mobil uygulamalarla öğrencilerin odaklanmalarına yardımcı, uzun süre evde kalmalarından dolayı amaçsız hareketler sergilemeleri yerine bir amaca hizmet eden etkinlik yapma imkânlarının olduğu da görülmektedir. Ancak tüm bu uygulamalar sanal ortamda sunulduğu ve teknoloji kullanımına dayandığı için alt yapı yetersizliği, ailelerin araçları nasıl kullanmaları gerektiğini tam olarak anlayamaması gibi sorunlar yaşandığı söylenebilmektedir.

Salgın başlangıcından itibaren özellikle canlı derslerde DEHB olan öğrencileri derslere katılım ve takip konusunda nasıl motive edecekleri, ortam düzenlemesinin nasıl olması gerektiği gibi çok sayıda konuda öğretmenlerin ailelerle iletişime geçerek yardımcı oldukları görülmüştür. Bu konuda öğretmenler çocuğu DEHB olan ailelerin çoğunluğunun gönüllü ve süreç boyunca sağlıklı iletişimi sürdürdüklerini belirtmişlerdir. Sosyal medyanın birbirleri ile iletişim sağlamada çok fazla kullanıldığı, hazırlanan bazı içeriklerin çocuklarının gelişim düzeyine uygun olmadığında ya da yeterli gelmediğinde öğretmenlerin ailelerle birlikte etkinlik, materyal tasarladıkları ifade edilmiş̧tir. Genel olarak bakıldığında sürecin başından beri tüm öğretmenlerin ya da uzmanların her bir DEHB olan öğrenciye ulaşmak ve destek olmak için ciddi çaba gösterdiği izlenimi edinilmiştir.

\section{Psiko-sosyal Destekte Yansimalar}

DEHB olan öğrencilerin üstesinden gelmek zorunda oldukları temel sorunlar dikkati, hareketleri ve dürtüleri denetlemedir. Bazı öğrenciler bu dürtülerin bastırılması ya da kontrol altına alınması için ilaç kullanmaktadır. Çocuğu ilaç kullanan ebeveynler normal şartlarda önce muayene olup ardından ilaç alabilmekteydi. Salgın sürecinde aileler ilaç rapor sürelerinin uzatılmasıyla ilaçlarına erişebilmişlerdir. Ancak ilaçların dozunu ayarlama noktasında doktorlarıyla telefonla görüşerek kendilerinin sorumluluk aldıklarını ifade etmişlerdir. Çocuğun belirtilerini yatıştırmak üzere aldıkları bu sorumluluk ebeveynlerin kaygı düzeyini artırmıştır. Evde kalmayla birlikte özellikle küçük yaşta olan öğrencilerin enerjilerini atmaları için planlanan rutin etkinlikler bozulmuş, kişilerarası etkileşimleri engellenmiştir. Dahası bu öğrenciler neden evde kalmak gerektiğini anlamakta güçlük yaşamışlardır. Engellenme duygusu (frustration) her bireyde olumsuz psiko-sosyal sonuçlar doğurabilir, ne var ki DEHB olan öğrenciler engellenme yaşadıklarında patolojik boyuta varabilen ruhsal sorunlar geliştirebilirler. Bununla beraber küçük yaş DEHB tanısı olan öğrenciler dikkatsiz ve özensiz olduklarından virüse yakalanma risklerinin yüksek oluşu ailelerinde büyük korku ve paniğe neden olmuştur. Ergenlerde de durum çok 
farklı olmamış, örneğin dışarıya çıkmalarına izin verilen süreden sonra eve döndüklerinde hijyen kurallarına uymada özensiz olmalarının ailelerinde tedirginliğe yol açtığı ifade edilmiştir. Bu süreçte DEHB olan öğrencilerde kendini kontrol etmede güçlük, davranışlarda ve düşüncelerde ataklık, huzursuzluk özellikle çevreyle iletişimin azalması ile içe kapanma, öfke nöbetleri gibi olumsuz sonuçların ortaya çıkmış olduğu gözlemlenmiştir.

MEB'in uzaktan eğitim platformuyla öğrencilerin süreci daha iyi anlamaları ve hızlı uyum sağlamalarına yönelik çalışmalar yaptı̆̆ gözlenmiştir. Örneğin "Elif ile Alp 1-2" adlı hikâye kitapları hazırlanmıştır. Ailelere destek olması amacıyla "Özel Eğitim ve Rehberlik Hizmetleri Bilgilendirme Hattı" kurulmuştur. Psikolojik sağlığı korumak için Özel Eğitim Genel Müdürlüğü’nün internet sitesinde yetişkinler, aileler ve gençler için bilgilendirme rehberi yayımlanmıştır. Bunların yanında aileler özellikle rehber öğretmenlerinin, danışmanlık merkezlerinin, üye oldukları derneklerin düzenlediği çevrimiçi etkinliklerle hem kendilerinin hem de çocuklarının psikolojik sağlıklarını korumak için çaba göstermişlerdir.

\section{Çıkarılan Dersler}

Eğitim-öğretimdeki kesintilerin olumsuz etkisini en aza indirmek için MEB, öğretmenler, sivil toplum kuruluşları, aileler çeşitli çalışmalar yapmışlardır. Ancak sunulan tüm hizmetler her aile için çeşitli nedenlerden erişilebilir olmamıştır. DEHB olan öğrenci ve ailelerine yönelik eğitim içeriklerinin zenginleştirilmesi, tüm içeriklere erişimin sağlanmasına imkân verecek alt yapının güçlendirilmesine ihtiyaç vardır. Ev ortamının sınıf ortamına dönüştürülmesi şüphesiz çok zordur. Uzaktan eğitim sürecinde ailelerin çocukları tarafından öğretmen gibi görülmemelerinin de disiplin sağlamada güçlük yarattığı unutulmamalıdır. Yapılan tüm çalışmalar yeterli midir? Elbette olmayabilir fakat beklenmedik bir anda oluşan duruma destek anlamında gösterilen refleks çok önemsenmelidir.

\section{Durum 7: Özel Yetenek}

\section{Uzaktan Eğitimde Yansımalar}

Türkiye'de ilkokul düzeyindeki özel yetenekli öğrenciler özel sınıflar, destek eğitim odası ve okul sonrası programlardaki zenginleştirilmiş eğitim firsatlarından yoksun kalmışlardır. EBA'da aileleri ve öğretmenleri bilgilendirmek için özel yeteneklilerin eğitimi alanında çalışan akademisyenler tarafından hazırlanan kısa videolar bulunmaktadır. Ancak özel yetenekli öğrencilere yönelik ayrı bir bölüm bulunmamaktadır. Ayrıca destek eğitim odası uygulamasında görev yapan öğretmenlerin ve Bilim ve Sanat Merkezleri (BİLSEM) öğretmenlerinin EBA'da kendi öğrencileri ile bir grup olușturamadıkları, bu nedenle de EBA'yı kullanamadıkları gözlemlenmiștir. Özel yetenekli öğrencilerin aileleri de örgün eğitimdeki EBA içeriklerinin çocukları için kolay olduğunu ancak çocuklarının destek eğitim odası öğretmeninin ya da BİLSEM öğretmenlerinin uygulamalarından etkili bir şekilde yararlandıklarını belirtmişlerdir. BİLSEM, özel okul ve destek eğitim odası öğretmenleri WhatsApp, Zoom, Google Duo gibi uygulamaları kullanarak öğrencilere her hafta eğitim hizmetleri sunmuşlardır. Bu eğitim hizmetleri kapsamında ağırlıklı olarak öğrencilerin yaratıcı, eleștirel ve araştırma becerilerini geliştirmeye yönelik etkinlikler kullanılmıştır. Öğretmenler "Anabilim ÜYEP Yayınları", Marilena Z. Leana-Taşçılar tarafından hazırlanan "COVID-19 Günlerinde Üstün Zekâlı Çocuklara Destek Aile Kitapçığı" ve Özel Eğitim ve Rehberlik Hizmetleri Genel Müdürlüğ̈̈’nün bünyesinde hazırlanan "Özelim Eğitimdeyim” mobil uygulamasında yer alan etkinlikleri kullanmışlar ya da bu etkinlikleri farklılaştırarak yeni etkinlikler tasarlamışlardır. Bunlara ek olarak robotik kodlama, akıl oyunları tasarlama, yazılım, edebiyat, astronomi, zooloji, sanat gibi farklı alanlarda Web 2.0 araçları kullanılarak çeşitli çalışmalar yapılmıştır. Örneğin özel yetenekli öğrenciler Voki ve Storybird gibi araçlar kullanarak masal seslendirmeleri yapmışlardır. Öğrencilere Scratch gibi programlarla kodlama becerileri kazandırılmıştır. Kahoot uygulaması ile öğrencilerle bilgi yarışmaları yapılııı̧ır. Bilim Kahramanları Derneği ve Bilim Deney Merkezi gibi kuruluşların desteği ile de öğrenciler çeşitli deney düzenekleri tasarlamışlar ve YouTube, Facebook, Instagram gibi sosyal medya platformlarında tasarımlarını paylaşmışlardır. Eskişehir'de destek eğitim odası uygulamasından yararlanan bir ilkokul birinci sınıf öğrencisi arduino, kablo ve bilgisayar programlarından yararlanarak tuşları havuç ve salatalıktan oluşan bir piyano düzeneği tasarlamıştır. Öğrencinin tasarımı çeşitli medya organlarında haber olarak yer almıştır. Bu etkinliklerin dışında MEB özel yetenekli öğrencilerin faydalanabilmesi için Gri Ceviz isimli mobil uygulamayı bünyesine dâhil etmiş ve ücretsiz olarak öğrencilerin kullanımına sunmuştur. Bu oyunla öğrencilerin bilişsel becerilerinin geliştirilmesinin hedeflendiği söylenebilir.

Türkiye'de ortaokul ve lise düzeyindeki öğrencilerin eğitiminde Fen Liseleri, Konservatuvarlar, Türk Eğitim Vakfi İnanç Türkeş Özel Lisesi (TEVITOL) gibi özel okullar, Üstün Yetenekliler Eğitimi Araştırma ve Uygulama Merkezi (ÜYEP) ve BİLSEM gibi okul sonrası programların eğitim içerikleri sınılı kalmış, kimi 
programlarda eğitim yapılamamıştır. Bu nedenle öğrenciler EBA ya da kimi okullarının hazırladığı çevrimiçi sistemler üzerinden örgün eğitimlerine devam etmişlerdir. Ancak özel yetenekli öğrenciler bireysel olarak ilgili oldukları alanlarda araştırmalar yapmış ve çeşitli projeler geliştirmişlerdir. Örneğin ortaokulda öğrenim gören özel yetenekli bir öğrenci, tüm dünya genelinde ve ülkeler bazında COVID-19 salgınındaki vaka ve ölüm sayısını istatistiksel olarak takip olanağı sunan bir çevrimiçi harita geliştirmiştir. Bu haritanın benzerlerine rastlanmaktadır ancak erken yaşlardaki bir öğrencinin böyle bir yazılım geliştirmesi dikkat çekici bir başarı olarak değerlendirilebilir. BILLSEM'lerde öğrenim gören müzik alanında yetenekli olan öğrenciler de performanslarını sosyal medya platformları üzerinden sergilemişlerdir.

İlkokul düzeyinden lise düzeyine kadar farklı kademelerde eğitim gören özel yetenekli öğrencilerin dijital becerilerinin üst düzeyde olması nedeniyle çevrimiçi eğitim sürecine kolaylıkla uyum sağlayabilmiş oldukları görülmektedir. Öğretmenler ve aileler de teknoloji bağlamında kendilerini geliştirme firsatı elde etmişlerdir. Uzaktan eğitim sürecinde özel yetenekli öğrencilerin zaman yönetimi, bireysel çalışma gibi becerileri gelişmiştir. Ancak kimi özel yetenekli öğrencilerde bilgisayar, tablet gibi teknolojik araçların kullanımı oldukça yoğunlaşmıştır. Uzaktan eğitim sürecinde ölçme ve değerlendirme süreci oldukça yetersiz kalmıştır. Öğretmenlerin öğrencilerin etkinliklerine yönelik görüşlerini bildirdikleri ancak etkinlik çalışmaları sürecinde yönlendirme yapamadıkları söylenebilmektedir. Uzaktan eğitim sürecinin etkileşimli olmaması bu durumun başlıca nedeni olabilir. Özel yetenekli öğrenciler için uzaktan eğitim sürecinde öğretmen-aile iş birliği etkili bir şekilde sağlanmıştır. Bu nedenle de etkili bir eğitim sürecinin geçirildiği söylenebilir. Özellikle erken yaşlardaki özel yetenekli öğrenciler, zaman ve mekân bağımlılığından uzak bir eğitim sürecinin mümkün olduğunun farkına varmışlardır. Ayrıca öğrenciler bireysel olarak kendilerine daha çok vakit ayırabilmişlerdir. Örneğin daha fazla kitap okuyabilme firsatı bulmuşlardır. Ancak salgın sürecinin sonlarına doğru öğrencilerin motivasyon düzeylerinde azalmalar görülmüştür. Ayrıca yüzme, futbol, voleybol gibi spor faaliyetlerine ara vermek zorunda kalmışlardır. Bu bağlamda salgın sürecinin doğasından kaynaklı olarak, öğrencilerin fiziksel ve sosyal ihtiyaçlarının sınırlı düzeylerde karşılandığı söylenebilir.

\section{Psiko-sosyal Destekte Yansımalar}

Özel yetenekli öğrenciler, akranlarına göre dünya genelini ilgilendiren sosyal konularda daha çok duyarlıdırlar. Salgının insan yaşamı üzerindeki olumsuz etkileri özellikle küçük yaş grubundaki özel yetenekli ögrencilerin kaygılanmalarına neden olmuş ancak öğrencilerin salgına yönelik yaptıkları araştırmalar sonucunda aşı, ilaç vb. tıbbi müdahalelerin iyi sonuçlar verebildiğini görmeleri kaygı düzeylerinin azalmasını sağlamıştır. Öte yandan öğrencilerin okuldan uzak olmaları nedeniyle arkadaşları ve öğretmenlerine yönelik yoğun özlem duygusu yaşadığı ve çevrimiçi yapılan görüşmelerin yeterli olmadığı gözlemlenmiştir. Aileler uzaktan eğitimin ilk başlarında öğrencinin akademik olarak gerileyebileceği düşüncesiyle endişelenmişlerdir. Öğrencilerin kendilerinin hazırlamıs oldukları günlük çalışma programlarına uymaları, ailelerin de kaygı düzeylerinin azalmasına neden olmuştur. Salgın sürecinde ebeveynler çocuklarının programlarını takip etme pratiklerini kontrol ederek eğitici rolünü üstlenmişlerdir. Bu nedenle de kimi zaman öğrenci ve ebeveyn arasında çatışma yaşanmıştır. $\mathrm{Bu}$ sorunlarını ise ortak kararlar ve uygulamalar yaparak çözmüşlerdir. Uzaktan eğitim sürecinde özel yetenekli öğrencilerin akranlarından uzak kalması nedeniyle sosyalleşme ihtiyaçları karşılanamamıştır. Bu süreçte özel yetenekli öğrencilerin akademik beceri bağlamında olumsuz etkilenmediği ancak sosyal ve duyuşsal olarak olumsuz etkilendiği söylenebilir.

Özel yeteneklilerin eğitimine yönelik oluşturulan sivil toplum örgütleri diğer özel eğitim gruplarına kıyasla daha sınırlı kalmaktadır. Özel Yeteneklilerin Eğitimi Derneği (ÖYEDER), Tüm Üstün Zekâlılar Derneği (TÜZDER), Türkiye Üstün Zekâlı ve Dahi Çocuklar Eğitim Vakfı (TÜZDEV) gibi dernekler, özel yetenekli öğrencilerin özellikleri, tanılanmaları, rehberlik hizmetleri gibi alanlarda sosyal medya platformlarında ailelere ve öğretmenlere yönelik seminerler düzenlemişlerdir. Diğer taraftan aynı kurumda eğitim gören özel yetenekli öğrencilerin ailelerinin WhatsApp grupları da bulunmaktadır. Bu gruplarda seminer bilgileri ve özel yetenekli öğrencilerin yapmış oldukları çalışmalar paylaşılmaktadır. Türkiye genelinde oluşturulan bir destek ağı söz konusu değildir. Bu durum salgın sürecinde de devam etmiştir.

\section{Çıkarılan Dersler}

Salgın sürecinde özel yeteneklilerin eğitimi incelendiğinde öğrencilerin, öğretmenlerin ve ailelerin uzaktan eğitime uyum sağladığı ve bu süreci etkili bir şekilde yönettikleri söylenebilir. Uzaktan eğitimde uygulanan ve etkili olan Web 2.0 araçlarının kullanımı normal eğitim sürecine de aktarılabilir. Ayrıca öğrencilerin ürünlerini daha büyük kitlelerle paylaşma firsatı sunan sosyal medya araçlarından da örgün eğitim sürecinde yararlanmaları gerektiği söylenebilir. Uzaktan eğitim süreci akademik olarak öğrenciler için her ne kadar yoğun 
ve etkili olsa da öğretmenlerin, öğrencilerin ve ailelerin örgün eğitimi daha çok benimsedikleri ve tercih ettikleri görülmektedir.

Salgın süreci genel olarak değerlendirildiğinde, örgün eğitim sistemine yönelik planlı bir alt yapı bulunduğu ancak özel yetenekli öğrencilere yönelik yapılan uygulamaların kurumların inisiyatifine bırakıldığı görülmüştür. Örgün eğitim sisteminde de özel yeteneklilere yönelik eğitimlerin standart bir planlaması bulunmamaktadır. Özel yetenek tanısı almış öğrencilerin bulunduğu ilkokullarda destek eğitim uygulama odası açmak zorunlu hale getirilmiş ancak bir öğretim programı oluşturulmamış olduğu söylenebilir. Benzer şekilde Türkiye'nin farklı bölgelerinde bulunan BİLSEM'lerde verilen eğitimler okullarda uygulanan eğitimlerle doğrudan ilişkili değildir ve standart bir program bulunmadığı görülmüşsür. Örgün eğitim sürecinde yaşanan bu sorun salgın sürecinde de ön plana çıkmıştır. Bu nedenle Türkiye'de özel yetenekli öğrencilerin eğitimine yönelik çerçeve bir program oluşturulmalıdır. Bununla birlikte özel yeteneklilerin eğitimine yönelik STK'lar desteklenmelidir.

\section{Tartışma}

COVID-19 salgınında Türkiye'deki farklı özel gereksinim gruplarına yönelik özel eğitim uygulamalarındaki durumu değerlendiren, bütüncül ve kapsamlı bir şekilde veri sunan alandaki bu ilk araştırmanın bulguları incelendiğinde; uzmanların yansıtmalarında uzaktan eğitimin içeriği, mobil uygulamalar, ölçme ve değerlendirme, değişen rol ve sorumluluklar, uzaktan eğitimde ihtiyaç duyulan psiko-sosyal destek, dijital okuryazarlık becerileri ve dijital eşitsizlik/bölünme konuları odak noktalar olarak dikkat çekmektedir. Bu araştırmanın odak noktaları arasında özellikle ortaya çıkan "değişen rol ve sorumluluklar" ile "uzman desteği ihtiyacı" bulguları daha önce yapılan araştırmaların (Asbury vd., 2020; Stankovic vd., 2020; Toseeb vd., 2020) bulguları ile benzerlik göstermektedir. Alanyazında benzerlik gösteren bu bulgular sıklıkla özel gereksinimi olan öğrenciler ve ailelerinin evde eğitim sürecinde yaşadıkları kaygılar ile açıklanmaktadır. Alanyazında da belirtildiği gibi kısıtlama sürecinde meydana gelen hızlı sosyal değişikliklerin ve okul kapanışlarının bir sonucu olarak özel gereksinimi olan ögrenciler ve ailelerinde endişeli ruh hali, öğrenci ve aile davranışlarında değişiklikler ve kaygıların ön planda olduğu görülmektedir (Asbury vd., 2020; Stankovic vd., 2020).

Araştırmanın bulguları uzaktan eğitimin devreye girmesiyle yaşanan bu kaygıların yedi özel gereksinim grubunda da benzer şekilde yansımaları olduğunu göstermektedir. Bu durumda salgının şu anki özel gereksinimi olan öğrencilerin ruh sağlığı üzerindeki etkileri, gerçekten endişe verici bir durum olarak değerlendirilebilir. Örneğin OSB olan bireylerin sosyal olarak izole ve yalnız olmalarının etkilerini ağır düzeyde hissettikleri (Pelton vd., 2020), normal gelişim gösteren bireylerden daha stresli oldukları ve intihara meyilli oldukları da ifade edilmektedir (Bishop-Fitzpatrick vd., 2017; Cooper vd., 2017). Bu araştırmada elde edilen bulgular incelendiğinde Stankovic ve diğerleri (2020) tarafından yapılan araştırma bulgularına benzer şekilde OSB'de kaygı ve strese bağlı bu davranış değişikliğinin aileler tarafından sıkça dile getirilen konular arasında olduğu görülmüştür. Şu da ifade edilmelidir ki, OSB'de hissedilen bu durum diğer özel gereksinim gruplarında bu kadar ciddi şekilde ortaya çıkmasa da özellikle küçük yaş grubunda huzursuzluk, davranış problemleri, uyku sorunları, ev içi rutine uyum sağlayamama ile kendini göstermektedir. Tüm bu sorunların arka planında ise okul kapanışları ile gün yüzüne çıkan okulların görünmeyen ama önemli bir destek sunan gizli kimliklerine de değinmek gerekmektedir. Okulların kapanması öğrenciler açısından duygusal yansımaları göz ardı edilemeyecek kadar önemli durumların oluşmasına sebebiyet verebilir. Öğrenciler arasında kaygı ve depresyon gibi psikolojik sorunlar, öğrenciler okul ile bağlantısını kaybetmeye başladıkça artabilmekte; bu da hem öğrencilerin hem de ailelerin öğretimin önemine olan inançlarını kaybetmeleriyle (Joyce \& Early, 2014; Pikulski vd., 2020) ile sonuçlanabilmektedir. Okul kapanışlarında bir diğer önemli çıkarım duygusal güvenlikle ilgili olabilir. Bazı öğrencilerin beslenme ve sosyalleşme ihtiyacını karşıladıkları hatta kendilerini güvende hissettikleri tek yer okulları olabilir. Bakım altındaki veya düşük gelirli hanedeki öğrenciler için, okullar hayatlarında tek bir rutin olabilir ve bir okulun sağladığı temel bakım desteği olmadan öğrenciler öğrenmeden uzaklaşabilir (Baker vd., 2020). Bu açıdan bakıldığında, kısıtlama sürecinde okul kapanışlarıyla faaliyetleri kısıtlamak ve evde kalmak, çoğu öğrenciyi etkilese de genellikle daha küçük sosyal gruplara sahip, sanal alternatifler bulmak için daha az firsata sahip ve farklı sosyo-ekonomik koşullardan gelen özel gereksinimi olan öğrencilerde, bu önemli bağlantı kaybı daha da hissedilecektir (McCallion, 2020).

Öte yandan COVID-19 salgını ve okul kapanışları tüm dünyada ailelerin hayatlarını olağanüstü bir şekilde etkilemiş olmakla birlikte aileler çocukları için yüz yüze sunulan destek hizmetlerinden aniden yoksun kalarak çocuklarının hem ebeveyni hem öğretmeni rolünü üstlenmişlerdir (Tarbox vd., 2020). Bu çalışmada da acil uzaktan eğitimin devreye girmesiyle beraber değişen aile rol ve sorumlukları tüm özel gereksinim gruplarında özellikle vurgulanan konulardan biri olarak göze çarpmaktadır. Gerek Türkiye'de gerekse diğer ülkelerde yapılan 
çalışmaların sonuçları; ebeveynlerin günlük rutinlerinde çocuklarının eğitim rollerini üstlenmeleriyle birlikte, sınırlı internet, teknolojik araç kullanamama, tek bir portal üzerinden tüm kaynakları tarayamama vb. nedenlerle bilgiye ulaşmada zorluk yaşamalarının stres ve kaygı düzeylerini yükselttiğini göstermiştir (Courtenay \& Perera, 2020; Douglas vd., 2020; Goldschmidt, 2020; Özer, 2020; Rose vd., 2020). Ebeveynlerin ev içindeki eğitimci rolünü üstlenmesiyle birlikte aile rol beklentilerinin çeşitlenerek arttığı vurgulanmaktadır (Bozkurt vd., 2020; Burke \& Dempsey, 2020; UNESCO, 2020b). Özellikle rutinleri değişen ve çevrimiçi eğitim materyalleriyle sık zaman geçirmek zorunda kalan özel gereksinimi olan öğrencilerin problem davranışlarında artış olması ve ebeveynlerin bunlarla baş etme stratejileri uzaktan eğitim odağında tartışılan konulardan biridir (Alexander vd., 2020; Courtenay \& Perera, 2020; Rose vd., 2020). Aile eğitim hizmetlerinin erken çocukluk döneminde bile zorunlu olmadığı Türkiye'de ebeveynlerin hem dijital okur-yazarlık becerileri hem de davranış problemleri ile belki de en yoğun kullandıkları başa çıkma yollarının sosyal medya hesapları üzerinden birbirlerini desteklemek, sorunlarını, beklentilerini ve taleplerini dile getirmek ve politika yapıcıların, uzmanların ve ögretmenlerin hatalarını eleştirmek olduğu söylenebilir.

Öğretmen/uzman tepkileri incelendiğinde ise salgın sürecinde herhangi bir eğitimden ya da uyum aşamasından geçmeden uzaktan eğitim sürecine dâhil olan öğretmenlerden öğrencilere destek olmaları beklendiği dikkat çekmektedir. Benzer şekilde, pek çok ülkede öğretmenlerin öğrencileriyle iletişime geçmesi istense bile öğretmenlere "uzaktan eğitim" ile ilgili eğitim sağlanan ülke sayısı çok sınırlıdır. Nitekim Avrupa ve Asya'da ülkelerin yalnızca $\% 20$ ila $\% 30$ 'unda öğretmenlere uzaktan eğitimle ilgili eğitim verildiği bilinmektedir (Çetinkaya-Aydın, 2020; Vegas, 2020). Bu durum benzer kaygıların Türkiye’ye özgü olmadığını ve daha önce örneği yaşanmamış olan salgın sürecinde yaşanabilecek sorunların ortak olduğuna işaret etmektedir. Bu belirsizlik ve değişen rol ve sorumluklar nedeniyle yukarıda ifade edilen kaygıların yaşanması normaldir. Önemli olan sürece yönelik mümkün olduğu kadar kısa bir zamanda ve acil olarak planlamaların yapılarak uygulamaya konmasıdır. Türkiye'de bu süreçte okul kapanışlarından kısa bir süre sonra başta MEB olmak üzere ilgili diğer kurumların özel gereksinimi olan öğrenciler ve ailelerinin ihtiyaç çağrılarına hızlı bir şekilde yanıt verici olduklarını görmek sevindiricidir. MEB'in özellikle uzaktan eğitimde geliştirdiği çeşitli mobil uygulamalarının yer aldığı platform aracılığıyla ve $8 \mathrm{~GB}$ ücretsiz internet erişimi ile ailelerin bir nebze de olsa nefes alabilmelerini sağladığı söylenebilmektedir. Yine özellikle MEB'in bu platform aracıllğıyla akademik etkinlikler ile ailelerin ve çocukların rahatlamasını sağlamayı amaçlayan sanal sosyal etkinlikler düzenlemesi de iyi uygulama örnekleri olarak düşünülebilir. Ancak sanal sosyal etkinliklerin yanı sıra bu etkinliklerin daha bütüncül olacak biçimde psiko-sosyal destek etkinliklerini de kapsayacak boyutta çeşitlendirilmesine gereksinim duyulmaktadır. Özel gereksinimi olan öğrencilerin hem sağlık hem psikoloji alanında desteklenmesinde destek topluluklarının etkisi çok büyüktür (Gulati vd., 2020; Landes vd., 2020). Bu süreçte ise ailelerin salgın sürecindeki temel ihtiyaçlarının ev içinde olumlu etkileşim kurma, davranış yönetimi, psikolojik sağlığın iyileştirilmesi konularında yoğunlaştı̆̆ söylenebilir (Courtenay \& Perera, 2020; Toseeb vd., 2020). Bu doğrultuda sosyal medya üzerinden yapılan bilgilendirmelerin farkındalık ve yaygınlaştırma açısından çok değerli olduğu ifade edilmekte (Thelwall \& Levitt, 2020), desteklerin sürekliliğgini sağlayabilmek için eğitimciler, ruh sağlığı çalışanları ve ailelerin iş birliği içinde çalıştığı destek ağı topluluklarına vurgu yapılmaktadır (Asbury vd., 2020; Courtenay, 2020; Hassiotis vd., 2020).

Özel gereksinimi olan öğrenciler ve aileleri salgın sürecinde karakteristik özellikleri bağlamında farklı desteklere ihtiyaç duysalar da hem öğrenciler hem de aileleri için duygusal desteğin önemli olduğu tartışılmaz bir konudur. İlgi ve empati pedagojisi olarak da adlandırılan yaklaşıma göre özellikle travmatik zamanlarda eğitimin ikinci öncelik, ilgi ve empatinin insanların temel ihtiyacı olduğu (Noddings, 2012) düşünüldüğünde, bu yaklaşımlara yönelik uygulamaların ortaya konulmasının ise birinci öncelik olarak ele alınması önerilmektedir. Bozkurt ve Sharma'ya göre (2020) her ne kadar uzaktan eğitime geçiş eğitimin sürekliliğini sağlamak açısından önemli olsa da COVID-19 sonrası yeni normalde öğrencilerin hatırlayacaklarının eğitsel içeriklerden ziyade bu süreçte neler hissettikleri olacağıdır. Dolayısıyla uzaktan eğitim uygulamalarında ilgi ve empati pedagojisinin ortaya çıkan duygusal/duyuşşal gereksinimleri de karşılamak açısından önemli olduğunun altı önemle çizilmektedir (Robinson vd., 2020). Bu şekilde özel gereksinimi olan öğrenciler ve aileleri COVID-19 ile ortaya çıkan zorlukları en az hasarla atlatabileceklerdir.

Özel gereksinimi olan öğrenciler ve aileleri için COVID-19 ile ortaya çıkan zorlukları en az hasarla atlatabilmelerinde dikkate değer bir diğer konu da eğitimin uzaktan eğitim sürecinde de hiçbir öğrencinin eğitimden geride kalmayacağı düşüncesini temel alan kapsayıcı eğitim çerçevesinde şekillendirilmesi gerekliliğidir. Kapsayıcı eğitim, tüm öğrencilerin eğitim süreçlerine ve hazırlanan materyallere ulaşımına eşit derecede önem veren bir yaklaşımdır (Ackah-Jnr, 2020; Armitage \& Nellums, 2020). Özel gereksinimi olan öğrencilere ve ailelerine yönelik uzaktan eğitim çalışmalarının bu yaklaşım temelinde hazırlanması, tüm dünyayla 
birlikte Türkiye'de de önemli salgın gündemlerinden biri olmuştur (Armitage \& Nellums, 2020; Berger vd., 2020; Bozkurt vd., 2020; Özer, 2020). Türkiye'de Özel Eğitim Hizmetleri Yönetmeliğine eğitim-öğretime ara verilen durumlarda uzaktan eğitime yönelik bir planlama eklemesi ve MEB öncülüğünde çok çeşitli sivil toplum kuruluşları, ögretmenler ve uzmanların iş birliğiyle uzaktan eğitime dayalı pek çok çalışmanın işe koşulması bu yaklaşımın bir sonucudur (Kavak, 2020; Özer, 2020).

MEB tarafından yapılan çalışmalarda oyun, etkinlik, konu anlatımı, canlı derslere dayalı çok çeşitli çevrimiçi materyallerden (videolar, e-kitaplar vb.) Zoom, BigBlueButton, Skype, Instagram canlı yayın, Facebook, Twitter gibi sosyal medya araçlarını içeren pek çok web tabanlı/çevrimiçi/online platformlardan yararlanıldığı dikkat çekmektedir. MEB, salgın sürecinde altyapısını güçlendirerek Türkiye Radyo Televizyon Kurumu (TRT) ile iş birliği yapmıştır. Böylece bu materyallere bilgisayar/tablet aracılığıyla ulaşım sağlanmakla birlikte, TRT EBA TV'de yayımlanan canlı derslerle de paydaşlara eğitimler sunmuştur. Bu yönüyle platformda materyal çeşitliliğine ve yaygın etkiye önem verildiği sonucuna ulaşılabilmektedir. Bu süreç gerek ülkemizde gerekse diğer ülkelerde bilişim çağıyla hız kazanan ve özel gereksinimi olan öğrencilerin ve ailelerinin güçlendirilmesi temelinde zengin teknolojik materyallerle desenlenen uzaktan eğitim uygulamalarının, salgın sürecinde bir kat daha ivme kazandığını göstermektedir (Bozkurt vd., 2020; Courtenay \& Perera, 2020; Goldschmidt, 2020; UNESCO, 2020). Bu süreçte ortaya konulan tüm olanaklarla hazırlanan pek çok çevrimiçi uygulamayla, ülkemize özgü ve bu süreçten sonra da kullanılabilecek uzaktan eğitim sistemi modelinin geliştirilmeye başlandığı söylenebilmektedir (Özer, 2020).

Uzaktan eğitim uygulamaları aynı anda ülkedeki hatta ülkeler arasında pek çok kişiye ulaşması, bireylerin kişisel zamanlarına dayalı olarak takip edilebilmesi gibi yönleriyle olumlu özellikler taşımasına rağmen, tartışılması gereken birtakım konuları da beraberinde getirmektedir (Pineda \& Corburn, 2020; Singh, 2020; Thelwall \& Levitt, 2020). Bu araştırma bulgularında özellikle içerik ve materyal çeşitlemesine duyulan ihtiyaçla birlikte önemle üzerinde durulan bir konu da bu süreçte ölçme ve değerlendirme sistemlerinin gerçekleştirilememiş olması ve sonuç odaklı kararlara/inisitayiflere bırakılmasıdır. COVID-19 ile acil uzaktan eğitime geçişle birlikte birçok ülkede geçme/kalma üzerine kurulu ölçme ve değerlendirme süreçleri askıya alınmış (Bozkurt vd., 2020) veya yeterli geçerlik ve güvenirlik çalışmaları olmaksızın bir anda çevrimiçi sınavlar yapılmaya başlamıştır (d’Orville, 2020). Bu nedenle yapılan planlamaların bu noktada yetersiz kaldığı görülmektedir.

Bir diğer önemle üzerinde durulması gereken konu ise COVID-19 salgınında çevrimiçi eğitimin yeni normuna uyum sağlamanın sosyal bölünmeyi vurgulama ve pekiştirme riskini gündeme getirmesi olmuştur. Sosyal bölünme ise dijital uçurumdan ortaya çıkmaktadır. Bu kapsamda değerlendirilmesi gereken öncelikli konulardan biri, bilgiye eşit erişimdir (Courtenay \& Perera, 2020; Pineda \& Corburn, 2020; Singh, 2020). Salgın sürecinde ülkemizdeki eğitim politikaları özel gereksinimi olan öğrencilere, ailelerine ve uzmanlara pek çok uzaktan eğitim platformu geliștirerek yaygın etkiyi amaçlasa da ülkenin her bölgesindeki paydaşlara ulaşımda sorunlar yaşanmıştır (Özer, 2020). Bu sorunlardan ilki, sosyo-ekonomik düzeyi düşük olan kitlelerin teknolojik araçlarının ve yeterliliklerinin olmaması, bu araçlara sahip olan bazı kitlelerin ise yaşadıkları bölgelerdeki internet hizmeti ağının yokluğu ya da internete erişimlerinin kısıtlı olmasıdır. Bir diğer sorun, internet erişimi olsa bile, alt yapıdan ve internet hızından kaynaklı olarak özellikle görsel etkinliklere ve oyunlara dayalı uygulamaların açılmasında ve akıcı işlemesinde sorunlar yaşanmasıdır. Konuyla ilgili olarak; Medya takip kurumu Ajans Pressin tech4i2 Press (http://ajanspress.com.tr/) verilerinden elde ettiği bilgilerde, bu sorunun tüm ülkelerde yaşanan genel bir sorun olduğu belirtilmiş, salgın sürecinde internet hızında düşüş yaşandığı saptanmıştır. Dolayısıyla bu süreçte birçok öğrenci ve ailenin çevrimiçi seçeneklere erişemeyeceği düşünüldüğünde acil uzaktan eğitim bazı öğrenciler için çevrimiçi bir cezaya (online penalty) dönüşebilmektedir (Qadir, 2020). Çevrimiçi cezanın yetersizliği ve dezavantajı olan öğrenciler (örn. akademik başarısı düşük olan öğrenciler, özel gereksinimi olan bireyler) için daha şiddetli olduğu bilinmektedir (Reich vd., 2020). Yoksulluk ve engellilik, Türkiye de dâhil olmak üzere tüm dünyada aynı madalyonun iki yüzüdür. Dahası, salgından iki kat etkilenen bu grupların ekonomik gerilemesi ve azalan gelirleri göz önüne alındığında (Jalali, vd., 2020) dijital yoksulluğun engellenmesi için özel gereksinimi olan öğrencilerin uzaktan eğitim planlamasının merkezinde olması gerekmektedir (Reich vd., 2020). Böyle bir süreçte okullar öğrencilerin uzaktan öğrenmelerini desteklemek için farklı düzeylerde aile denetimine sahip olacağını kabul etmeli ve kamu televizyonunu, basılı paketleri veya diğer yaklaşımları kullanarak dijital olmayan alternatifleri planlamalıdırlar (Colizzi vd., 2020).

Erișilebilirlikle ilgili tartışılması gereken bir diğer konu ise geliştirilen uygulamaların içeriğidir. Ülkemizdeki uzaktan eğitim uygulamaları incelendiğinde, içeriklerin daha çok büyük yaş gruplarındaki öğrencilere yönelik olduğu ve erken çocukluk özel eğitiminde yer alan öğrencilere ilişkin içeriklerin sınırlı sayıda olduğu dikkat çekmektedir. Bu durum ülkemizdeki uzaktan eğitim uygulamalarının kapsayıcılık ve yaygın etkisini 
azaltan bir durum olup, özellikle gelişmiş ülkelerde erken dönemde özel gereksinimi olan çocuğa sahip ailelerin güçlendirilmesine dayalı çalışmaların bu süreçte giderek hız kazandığı dikkat çekmektedir (Alexander vd., 2020). Buna ek olarak, ülkemizde hazırlanan pek çok materyalin paydaşların okuryazarlık becerilerini gerektirmesi sorunu, çoğu ülkede tartışlan konular arasında yer almaktadır (Courtenay \& Perera, 2020; Mentally Handicapped Organization [MENCAP], 2020).

COVID-19'a ilişkin özel gereksinimi olan birey, aileleri ve eğitimcileri/uzmanları ve yapılan teorik ve pratik uygulamaların var olan durumlarını betimlemeye ve ilgili uygulamaların belirlenen amaçlarına yönelik etkilerini ortaya koymaya yönelik spesifik alan bazlı ve ulusal bazda araştırmalar yapılması oldukça önemlidir. Bu bağlamda atılan önemli adımlardan biri Türkiye Bilimsel ve Teknolojik Araştırma Kurumunun (TÜBİTAK) pandemi sürecinde TÜBİTAK 1001 COVID-19 özel çağrılı program ile proje çağrısına çıkması olmuștur. Bu çağrı kapsamında Prof. Dr. İbrahim H. DiKEN'in yürütücülüğünde 120K170 proje numarası ve "Proje EV-DES: Erken Çocukluk Döneminde Gelişimsel Gerilik/Yetersizlik Tanılı Çocukların Ebeveynlerine Yönelik Çevrim içi Evde Destek Programının Tasarlanması ve Uygulanması (www.evdedestekprojesi.com)" adıyla ve Doç. Dr. Salih RAKAP'1n yürütücülüğünde 120K259 proje numarası ve "COVID-19 Sürecinin Özel Gereksinimli Çocuklar ve Ailelerinin Yaşam Kalitesi Üzerine Etkisi: Bir Karma Desen Çalışması” adıyla iki proje Temmuz 2020-Aralık 2020 tarihi arasında desteklenmiştir.

Sonuç olarak, Türkiye'deki uzaktan eğitim çalışmalarının her öğrencinin önemli olduğu felsefesiyle yaygın etkiyi amaçlayan özelliklerde tasarlanması diğer ülkelerdeki çalışmalarla paralellik gösterip; STK'ların çalışmalarının hızlandııılması, internet alt yapısının güçlendirilmesi, geliştirilen materyallerin zenginleştirilmesi ve tam erişilebilirliğin sağlanması gibi konular halen çözüm beklemektedir. Bununla birlikte Türkiye'de kısıtlama sürecinde bu ani ve kısa sürede uzaktan eğitime geçişe hızlı bir tepkiyle yanıt verildiği, sürecin planlı bir geçişle yönetildiği ve bu süreçte iyi uygulama örneklerinin olduğu da söylenebilmektedir. Bu araştırma sonuçlarının Türkiye'nin okul kapanışlarına verdiği yanıtlarda çeşitli yaklaşımları ve birçok örnek uygulamayı vurgulayarak, COVID-19'da yeni dalgaların yaşanma ihtimaline dair ilerideki zorlu günleri ele almak ve gelecekteki okul kesintilerine hazırlanmak için yararlı bir rehberlik sunabileceğine inanılmaktadır. Genel olarak ülke çapındaki devlet kurumları tarafından yürütülen dikkatli ama hızlı çalışmaların etkileyici olduğu söylenebilir ancak başta karar vericiler olmak üzere özel eğitim alanında çalışan uzmanların ve ilgili tüm paydaşların çabalarını hızlandırma çağrısına gereksinim duyulmaktadır. Bu kapsamda çalışma OSB, zihin yetersizliği, işitme yetersizliği ve görme yetersizliği, dil ve konuşma bozukluğu, DEHB olan ve özel yetenekli çocuklar bağlamında yedi durum ile sınırlıdır. Ancak Uzaktan eğitim platformunda yapılan planlamanın bu çalışma haricindeki diğer özel gereksinim gruplarında ayrı ayrı olarak ele alınmasını sağlamak için ilave çabalara ihtiyaç vardır. Bu kapsamda özel gereksinimi olan öğrencilerin eğitim ve sosyal hizmetler gibi hakları, COVID-19 salgını kapsamında korunmalı ve salgın kapsamında yeni eylem planları oluşturulmalıdır. Hatta bu durum yalnızca salgın kapsamında kalmayarak acil ya da olağanüstü durumları kapsayacak şekilde ele alınmalıdır. Çünkü Türkiye doğal olayların sıkça görüldüğü bir coğrafik yapıya sahiptir ve sel, toprak kayması, deprem gibi doğal afetler geçmişte yaşanmış ve yaşanmaya da devam etmektedir. Bu açıdan salgın ya da benzer durumlar için aciliyetle ülkemizde özel gereksinimi olan öğrenciler ve ailelerin temel ihtiyaçlarının neler olduğunu saptamaya yönelik niceliksel ve niteliksel veri toplamak ve bu verilerin ayrıştırılmasını sağlamak, sırada bekleyen pek çok konunun çözüme kavuşturulması ve planlanması için bir gereklilik olarak karşımıza çıkmaktadır. Bu planlamaların kapsayıc1/bütüncül olması ve gerçeğe dönüştürülebilmesini sağlamak ise özel gereksinimi olan öğrenciler ve destekçileri ile anlamlı bir istişare, politika ve program düzeyinde liderlik ve özel bütçe çizgileri gerektirecektir. $\mathrm{Bu}$ doğrultuda araştırmanın karar vericiler, okullar/kurumlar, uzmanlar ve ailelere yönelik ve son olarak yeni normal için birtakım önerileri bulunmaktadır.

\section{Karar Vericilere Yönelik Öneriler}

1. COVID-19 ve özel gereksinimli bireyler üzerinde etkisi farklı kurum ve kuruluşlar tarafindan desteklenecek kapsamlı ve spesifik projeler ya da araştırmalar ile araştırılmalı ve raporlaştırılmalıdır.

2. Özel gereksinimi olan öğrencilerin eğitimlerine yönelik salgın ya da krize yönelik durumlar için stratejik planlar yapılmalıdır.

3. Türkiye genelinde internet alt yapısı ve erişim için çalışmalar hızlandırılmalıdır.

4. Teknolojik materyal desteğine ihtiyaç duyulan bölgelere gerekli destek materyallerinin sağlanmasına yönelik çalışmalar planlanmalıdır. 
5. Uzaktan eğitim uygulamalarının sürdürülebilirliğine ilişkin izleme ve denetleme için sistemli bir model geliştirilmelidir.

6. MEB Dijital eğitim platformu EBA'da yer alan ders içeriklerine her bir yetersizlik grubu kapsamında içerik ve materyaller eklenmeli ve zenginleştirilmelidir.

7. Erken çocukluk dönemindeki/okul öncesi dönemdeki özel gereksinimi olan öğrenciler ve ailelerine yönelik online/çevrimiçi içerikler zenginleştirilerek alan uzmanları tarafından güncellenmelidir.

8. Uzaktan eğitimde ölçme ve değerlendirme süreçlerinin objektif yürütülebilmesine yönelik bir kılavuz geliştirilmelidir.

9. Ailelerin doğrudan uzmanlarla iletişime geçebileceği online/çevrimiçi profesyonel danışmanlık platformu oluşturulmalıdır.

10. Çalışan özel gereksinimi olan yetişkinlerin evden çalışma rutini oluşturabilmesi için $7 / 24$ ulaşılabilir "destek hatları" oluşturulmalıdır.

11. Paydaşların hizmetlere ulaşmasına kolaylık sağlaması açısından, uzaktan eğitime yönelik pek çok platform tek bir portalda birleştirilmelidir.

12. Uzaktan eğitim programlarında ve uygulamalarında, yazı puntolarının, görsellerdeki netlik ve kontrastın düzenlenmesinde uzman desteğinden yararlanılmalıdır.

13. Öğretmenlerin teknolojik bilgi ve becerilerini desteklemek amacıyla, hizmet öncesi ve hizmet sırasında dijital içerik geliştirmesine yönelik eğitimler verilmelidir.

\section{Okul/Kurumlar ve Uzmanlara Yönelik Öneriler}

1. Öğretmenlere/uzmanlara kriz yönetiminde uzaktan eğitimde özel gereksinim gruplarına göre içerik ve materyal uyarlama becerisini kazandırmaya yönelik eğitimler verilmelidir.

2. Sadece eğitsel destek değil psikolojik destek anlamında da yönlendirici olabilecekleri öğretmen güçlendirme çalışmaları yapılabilir.

3. Özel gereksinimi olan öğrenciler ve aileleri için kurumlar aracıllı̆̆ıla haftalık online/çevrimiçi rutin görüşmeler düzenlenerek rehberlik sunulmalı ve örnek uygulama videoları paylaşılmalıdır.

4. Beceri ve davranış öğretiminde uzmanlar arası (örn., dil konuşma terapisti ve özel eğitim uzmanı) iş birliği için etkinlik takvimi hazırlanmalıdır.

5. Ailelerin ihtiyaç duydukları konularda sosyal ağlar kurulmalı ve uzaktan aile eğitimleri düzenlenmelidir.

\section{Ailelere Öneriler}

1. Aileler kendi aralarında paylaşım yapabilecekleri sosyal ağ destek toplulukları oluşturmalıdır.

2. Aileler salgın sonrasında da hazırlıklı olmak amacıyla çocukları ile ev rutini ve nitelikli vakit geçirmeye yönelik etkinlik havuzu oluşturmalıdır.

3. Aileler çocuklarının akademik gelişimlerinin yanı sıra sosyal ve duyuşsal gelişimlerini destekleyici eğitim seminerlerine katılmalıdırlar.

\section{Yeni Normal ve İkinci Dalga Olasılığına Yönelik Öneriler}

1. Örgün eğitim sistemi gibi uzaktan eğitim sisteminin de MEB tarafından özel gereksinimi olan öğrencilere yönelik tüm okul basamaklarına ilişkin hazırlanması için acil bir planlama yapılmalı ve hayata geçirilmelidir.

2. Ülke politikası olarak sivil toplum kuruluşlarının alt yapıları güçlendirilerek uzaktan eğitim çalışmaları hızlandırılmalıdır.

3. Türkiye'ye özgü uzaktan eğitim portallarının geliştirilmesine yönelik çalışmalar ivme kazanmalıdır.

4. Uzaktan eğitim sürecinde öğretmenlerden neler beklendiğine yönelik bir çerçeve çizilerek nasıl bir yol izleneceğine ilişkin mesleki gelişim programları geliştirilmelidir. 
5. Salgın sürecinde etkili olan teknolojik araçların kullanımı örgün eğitim sürecine de aktarılmalıdır.

6. Uzaktan eğitim sürecine dâhil olamayan aileler ve vakalara yönelik bilgilendirici kitapçıklar ve iletişim becerilerini destekleyici resimli broşürler hazırlanmalıdır.

7. Yüz yüze terapinin gerekli olduğu durumlarda alınması gereken önlemler kapsamında bilgilendirici video örnekleri ve broşürler paylaşılmalıdır.

\section{Yazarların Katkı Düzeyleri}

Çalışmanın birinci yazarı çalışma konusu, araştırmanın yöntem ve desenini belirlemiş, veri toplama, verilerin analizi ve çalışma bulgularının raporlanması süreçlerinde görev almıştır. Çalışma da yer alan diğer yazarlar, veri toplama, verilerin analizi ve çalışma bulgularının raporlanması süreçlerinde görev almışlardır.

\section{Teşekkür}

Pandemi sürecinde araştırmamıza bilgi sağlayan kurum koordinatörlerine, öğretmenlere ve özel gereksinimli çocuğa sahip ailelere çok teşekkür ederiz. 


\section{Kaynaklar}

Ackah-Jnr, F. R. (2020). Inclusive education, a best practice, policy and provision in education systems and schools: The rationale and critique. European Journal of Education Studies, 6(10), 171-183. https://doi.org/10.5281/zenodo.3605128

Ajans Press. (2020, Haziran 26). Medya takibi. http://ajanspress.com.tr/

Alexander, R., Ravi, A., Barclay, H., Sawhney, I., Chester, V., Malcolm, V., Brolly, K., Mukherji, K., Zia, A., Tharian, R., Howell, A., Lane, T., Cooper, V., \& Langdon, P. E. (2020). Guidance for the treatment and management of Covid-19 among people with intellectual disabilities. Journal of Policy and Practice in Intellectual Disabilities, 17(3), 256-269. https://doi.org/10.1111/jppi.12352

Armitage, R., \& Nellums, L. B. (2020). The COVID-19 response must be disability inclusive. The Lancet Public Health, 5(5), e257. https://doi.org/10.1016/S2468-2667(20)30076-1

Asbury, K., Fox, L., Deniz, E., Code, A., \& Toseeb, U. (2021). How is COVID-19 affecting the mental health of children with special educational needs and disabilities and their families? Journal of Autism and Developmental Disorders, 51(5), 1772-1780. https://doi.org/10.1007/s10803-020-04577-2

Baker, S. R., Farrokhnia, R. A., Meyer, S., Pagel, M., \& Yannelis, C. (2020). How does household spending respond to an epidemic? Consumption during the 2020 Covid-19 pandemic. The Review of Asset Pricing Studies, 10(4), 834-862. https://doi.org/10.1093/rapstu/raaa009

Bartlett, L., \& Vavrus, F. (2016). Rethinking case study research: A comparative approach. Taylor and Francis.

Berger, Z. D., Evans, N. G., Phelan, A., \& Silverman, R. D. (2020). Covid-19: Control measures must be equitable and inclusive. The British Medical Journal, 368, m1141. https://doi.org/10.1136/bmj.m1141

Bilim Kurulu [Science committee]. (2020). Halk Sağll̆̆g Genel Müdürlüğ̈̈ 2019-nCoV săglı çalışanlarl rehberi. [General Directorate of Public Health 2019-nCoV health workers directory]. https://hsgm.saglik.gov.tr/depo/haberler/ncov/2019-nCov_Hastal_Salk_alanlar_Rehberi.pdf

Bishop-Fitzpatrick, L., Minshew, N. J., Mazefsky, C. A., \& Eack, S. M. (2017). Perception of life as stressful, not biological response to stress, is associated with greater social disability in adults with autism spectrum disorder. Journal of Autism and Developmental Disorders, 47(1), 1-16. https://doi.org/10.1007/s10803016-2910-6

Bozkurt, A., Jung, I., Xiao, J., Vladimirschi, V., Schuwer, R., Egorov, G., Lambert, S. R., Al-Freih, M., Pete, J., Olcott, Jr. D., Rodes, V., Aranciaga, I., Bali, M., Alvarez, Jr. A. V., Roberts, J., Pazurek, A., Raffaghelli, J. E., Panagiotou, N., De Coëtlogon, P., ... Paskevicius, M. (2020). A global outlook to the interruption of education due to COVID-19 pandemic: Navigating in a time of uncertainty and crisis. Asian Journal of Distance Education, 15(1), 1-126. https://doi.org/10.5281/zenodo.3878572

Bozkurt, A., \& Sharma, R. C. (2020). Emergency remote teaching in a time of global crisis due to coronavirus pandemic. Asian Journal of Distance Education, 15(1), i-vi. https://doi.org/10.5281/zenodo.3778083

Burke, J., \& Dempsey, M. (2020). Covid-19 practice in primary schools in Ireland report. https://www.maynoothuniversity.ie/education/news/covid-19-practice-primary-schools-report

Callaway, B., \& Li, T. (2020). Understanding the effects of tennessee's open covid-19 testing policy: Bounding policy effects with nonrandomly missing data. https://www.semanticscholar.org/paper/Understandingthe-Effects-of-Tennessee\%27s-Open-with-Callaway-Li/18622e0c003400892b33c7f4b39e08af553ee9a6

Cascella, M., Rajnik, M., Cuomo, A., Dulebohn, S. C., \& Di Napoli, R. (2020). Features, evaluation and treatment coronavirus (COVID-19). https://pubmed.ncbi.nlm.nih.gov/32150360/

Cluver, L., Lachman, J. M., Sherr, L., Wessels, I., Krug, E., Rakotomalala, S., Blight, S., Hillis, S., Bachman, G., Green, G., Butchart, A., Tomlinson, M., Ward, C. L., Doubt, J., \& McDonald, K. (2020). Parenting in a time of COVID-19. Lancet, 395(10231), e64. https://doi.org/10.1016/S0140-6736(20)30736-4

Colizzi, M., Bortoletto, R., Silvestri, M., Mondini, F., Puttini, E., Cainelli, C., Gaudino, R., Ruggeri, M., \& Zoccante, L. (2020). Medically unexplained symptoms in the times of Covid-19 pandemic: A case-report. Brain, Behavior, and Immunity-Health, 5, Article 100073. https://doi.org/10.1016/j.bbih.2020.100073 
Cooper, K., Smith, L. G. E., \& Russell, A. (2017). Social identity, self-esteem, and mental health in autism. European Journal of Social Psychology, 47(7), 844-854. https://doi.org/10.1002/ejsp.2297

Courtenay, K. (2020). Covid-19: Challenges for people with intellectual disability. The British Medical Journal, 369, m1609. https://doi.org/10.1136/bmj.m1609

Courtenay, K., \& Perera, B. (2020). COVID-19 and people with intellectual disability: Impacts of a pandemic. Irish Journal of Psychological Medicine, 37(3), 231-236. https://doi.org/10.1017/ipm.2020.45

Çetinkaya-Aydın, G. (2020). Covid-19 salgını sürecinde ögrretmenler [Teachers during the Covid-19 outbreak]. https://tedmem.org/covid-19/covid-19-salgini-surecinde-ogretmenler

Djuraskovic, I., \& Arthur, N. (2011). Heuristic inquiry: A personal journey of acculturation and identity reconstruction. The Qualitative Report, 15(6), 1569-1593. https://doi.org/10.46743/2160$\underline{3715 / 2010.1361}$

d'Orville, H. (2020). COVID-19 causes unprecedented educational disruption: Is there a road towards a new normal? Prospects, 49, 11-15. https://doi.org/10.1007/s11125-020-09475-0

Douglass, B. G., \& Moustakas, C. E. (1985). Heuristic inquiry: The internal search to know. Journal of Humanistic Psychology, 25(3), 39-55. https://doi.org/10.1177/0022167885253004

Douglas, M., Katikireddi S. V., Taulbut, M., \& Mckee, M. (2020). Mitigating the wider health effects of covid-19 pandemic response. The British Medical Journal, 369, m1557. https://doi.org/10.1136/bmj.m1557

Erken Çocukluk Döneminde Gelişimsel Gerilik/Yetersizlik Tanılı Çocukların Ebeveynlerine Yönelik Çevrim İçi Evde Destek Dijital Platformu. (2020, 4 Temmuz). Proje EV-DES. https://www.evdedestekprojesi.com/

Fiorillo, A., \& Gorwood, P. (2020). The consequences of the COVID-19 pandemic on mental health and implications for clinical practice. European Psychiatry, 63(1), 1-2. https://doi.org/10.1192/j.eurpsy.2020.35

Goldschmidt, K. (2020). The COVID-19 pandemic: Technology use to support the wellbeing of children. Journal of Pediatric Nursing, 53, 88-90. https://doi.org/10.1016/j.pedn.2020.04.013

Gulati, G., Fistein, E., Dunne, C. P., Kelly, B. D., \& Murphy, V. E. (2020). People with intellectual disabilities and the COVID-19 pandemic. Irish Journal of Psychological Medicine, 38(2), 158-159. https://doi.org/10.1017/ipm.2020.66

Hassiotis, A., Ali, A., Courtemanche, A., Lunsky, Y., McIntyre, L. L., Napolitamo, D., van der Nagel, J., \& Werner, S. (2020). In the time of the pandemic: Safeguarding people with developmental disabilities against the impact of coronavirus. Journal of Mental Health Research in Intellectual Disabilities, 13(2), 63-65. https://doi.org/10.1080/19315864.2020.1756080

Işı1k, A., \& Akbaş, E. (2019). Özel gereksinimli çocuklara sahip olan ailelerin evlilik yaşamına toplumsal cinsiyet odaklı yaklaşım [Gender based approach to the marital life of the families having children with special needs]. Social Sciences Research Journal, 8(2), 93-110. https://dergipark.org.tr/tr/download/articlefile/730566

İçişleri Bakanlığı [Ministry of Interior]. (2020). 09.04.2020 tarihli özel gereksinimi olan çocuklar ve gençler genelgesi [Children and youth with special needs circular dated 09.04.2020]. https://www.icisleri.gov.tr/81-il-valiligine-ozel-gereksinimi-olan-cocuk-ve-gencler-genelgesi

Jalali, M., Shahabi, S., Bagheri-Lankarani, K., Kamali, M., \& Mojgani, P. (2020). COVID-19 and disabled people: $\begin{array}{lllll}\text { Perspectives from Iran. Disability \& Society, 35(5), 844-847. } & \text {. }\end{array}$ https://doi.org/10.1080/09687599.2020.1754165

Joyce, H. D., \& Early, T. J. (2014). The impact of school connectedness and teacher support on depressive symptoms in adolescents: A multilevel analysis. Children and Youth Services Review, 39, 101-107. https://doi.org/10.1016/j.childyouth.2014.02.005

Kavak, İ. (2020). Pandemi sürecinde özel eğitim [Special education during the pandemic]. https://www.insamer.com/tr/uploads/pdf/etkinlik-pandemi-surecinde-ozel-egitim.pdf 
Koca, F. (2020, 11 Mart). Turkey remains firm, calm as first coronavirus case confirmed. Daily Sabah. https://www.dailysabah.com/turkey/turkey-remains-firm-calm-as-first-coronavirus-caseconfirmed/news

Kuper, H., Banks, L. M., Bright, T., Davey, C., \& Shakespeare, T. (2020). Disability-inclusive COVID-19 response: What it is, why it is important and what we can learn from the United Kingdom's response. Wellcome Open Research, 5(79), 1-8. https://doi.org/10.12688\%2Fwellcomeopenres.15833.1

Landes, S. D., Stevens, D., \& Turk, M. A. (2020). COVID-19 and pneumonia: Increased risk for individuals with intellectual and developmental disabilities during the pandemic. https://lernercenter.syr.edu/wpcontent/uploads/2020/04/Landes.Stevens.Turk_..pdf

McCallion, P. (2020). Social work response needed to the challenge of COVID-19 for aging people with intellectual and developmental disabilities. Journal of Gerontological Social Work, 63(6-7), 595-597. https://doi.org/10.1080/01634372.2020.1769791

McConnell, D., \& Savage, A. (2015). Stress and resilience among families caring for children with intellectual disability: Expanding the research agenda. Current Developmental Disorders Reports, 2(2), 100-109. https://doi.org/10.1007/s40474-015-0040-z

McStay, R. L., Trembath, D., \& Dissanayake, C. (2014). Stress and family quality of life in parents of children with autism spectrum disorder: Parent gender and the double ABCX model. Journal of Autism and Developmental Disorders, 44(12), 3101-3118. https://doi.org/10.1007/s10803-014-2178-7

Mentally Handicapped Organization. (2020). Information and advice about changes to the care act during coronavirus pandemic. $\quad$ https://www.mencap.org.uk/sites/default/files/202004/Information\%20and\%20advice\%20about\%20Care\%20Act\%20asements\%20final.pdf

Moustakas, C. E. (1990). Heuristic research: Design, methodology, and applications. Sage.

Nicola, M., Alsafi, Z., Sohrabi, C., Kerwan, A., Al-Jabir, A., Iosifidis, C., Agha, M., \& Agha, R. (2020). The socio-economic implications of the coronavirus pandemic (COVID-19): A review. International Journal of Surgery, 78, 185-193. https://doi.org/10.1016\%2Fj.ijsu.2020.04.018

Noddings, N. (2012). The caring relation in teaching. Oxford Review of Education, 38(6), 771-781. https://doi.org/10.1080/03054985.2012.745047

Organisation for Economic Cooperation and Development. (2020). A framework to guide an education response to the COVID-19 Pandemic of 2020. OECD Publishing.

Özer, M. (2020). Türkiye'de COVID-19 salgını sürecinde Milli Eğitim Bakanlığı tarafından atılan politika adımları [Educational policy actions by the Ministry of National Education in the times of COVID-19]. Kastamonu Education Journal, 28(3), 1124-1129. https://doi.org/10.24106/kefdergi.722280

Pelton, M. K., Crawford, H., Robertson, A. E., Rodgers, J., Baron-Cohen, S., \& Cassidy, S. (2020). Understanding suicide risk in autistic adults: Comparing the interpersonal theory of suicide in autistic and non-autistic samples. Journal of Autism and Developmental Disorders, 50(10), 3620-3637. https://doi.org/10.1007/s10803-020-04393-8

Pikulski, P. J., Pella, J. E., Casline, E. P., Hale, A. E., Drake, K., \& Ginsburg, G. S. (2020). School connectedness and child anxiety. Journal of Psychologists and Counsellors in Schools, 30, 13-24. https://doi.org/10.1017/jgc.2020.3

Pineda, V. S., \& Corburn, J. (2020). Disability, urban health equity, and the coronavirus pandemic: Promoting cities for all. Journal of Urban Health, 97, 336-341. https://doi.org/10.1007/s11524-020-00437-7

Qadir, J. (2020). The triple imperatives of online teaching: Equity, inclusion, and effectiveness. https://edarxiv.org/zjdc7/

Reich, J., Buttimer, C. J., Fang, A., Hillaire, G., Hirsch, K., Larke, L. R., Littenberg-Tobias, J., Moussapour, R., Napier, A., Thompson, M., \& Slama, R. (2020). Remote learning guidance from state education agencies during the COVID-19 pandemic: A first look. https://edarxiv.org/437e2/ 
Robinson, H. A., Al-Freih, M., \& Kilgore, W. (2020). Designing with care: Towards a care-centered model for online learning design. The International Journal of Information and Learning Technology, 37(3), 99108. https://doi.org/10.1108/IJILT-10-2019-0098

Rose, J., Willner, P., Cooper, V., Longdon, P. E., Murphy, G., \& Stenfert-Kroese, B. (2020). The effect on and experience of families with a member who has intellectual and developmental disabilities of the COVID19 pandemic in the UK: Developing an investigation. International Journal of Developmental Disabilities, Advance Online Publication, 1-3. https://doi.org/10.1080/20473869.2020.1764257

Sancak, M., \& Çöl, M. (2020). Türkiye'de COVID 19 pandemisinin kronolojik olarak incelenmesi. O. Memikoğlu \& V. Genç (Eds.), COVID-19 [COVID-19] içinde (ss. 201-217). Ankara Üniversitesi Basımevi.

Seggie, F. N., Sart, G., \& Akbulut-Yıldırmış, M. (2017). Nitel araştırmaların raporlaştırılması. F. N. Seggie \& Y. Bayburt (Eds.), Nitel araştırma: Yöntem, teknik, analiz ve yaklaşımları [Qualitative research: Methods, techniques, analysis and approaches] içinde (ss. 371-384). Anı Yayıncılık.

Singh, S. (2020). Disability ethics in the coronavirus crisis. Journal of Family Medicine and Primary Care, 9(5), 2167-2171. https://doi.org/10.4103/jfmpc.jfmpc_588_20

Stake, R. E. (1995). The art of case study research. Sage.

Stankovic, M., Jelena, S., Stankovic, M., Shih, A., Stojanovic, A., \& Stankovic, S. (2020). The Serbian experience of challenges of parenting children with autism spectrum disorders during the COVID-19 pandemic and the state of emergency with the police lockdown. https://doi.org/10.2139/ssrn.3582788

Tarbox, C., Silverman, E. A., Chastain, A. N., Little, A., Bermudez, T. L., \& Tarbox, J. (2020). Taking action: 18 simple strategies for supporting children with autism during the COVID-19 pandemic. https://psyarxiv.com/96whj/

Thelwall, M., \& Levitt, J. M. (2020). Retweeting COVID-19 disability issues: Risks, support and outrage. El Profesional De La Información, 29(2), 1-6. https://doi.org/10.3145/epi.2020.mar.16

Ting, D. S. W., Carin, L., Dzau, V., \& Wong, T. Y. (2020). Digital technology and COVID-19. Nature Medicine, 26(4), 459-461. https://doi.org/10.1038/S41591-020-0824-5

Toseeb, U., Asbury, K., Code, A., Fox, L., \& Deniz, E. (2020). Supporting families with children with special educational needs and disabilities during COVID-19. Research Brief. https://psyarxiv.com/tm69k

United Nations Children's Fund. (2020). UNICEF and Microsoft launch global learning platform to help address COVID-19 education crisis. https://www.unicef.org/press-releases/unicef-and-microsoft-launch-globallearning-platform-help-address-covid-19-education

United Nations Educational, Scientific and Cultural Organization. (2020a). COVID-19 education response. https://en.unesco.org/covid19/educationresponse/globalcoalition

United Nations Educational, Scientific and Cultural Organization. (2020b). COVID-19 educational disruption and response. https://en.unesco.org/covid19/educationresponse

Vegas, E. (2020). School closures, government responses, and learning inequality around the world during COVID 19. https://www.brookings.edu/research/school-closures-government-responses-and-learninginequality-around-the-world-during-covid-19/

World Health Organization. (2020). Coronavirus disease (COVID-19) pandemic. https://www.who.int/emergencies/diseases/novel-coronavirus-2019

Yıldırım, A., \& Şimşek, H. (2016). Sosyal bilimlerde nitel araştırma yöntemleri [Qualitative research methods in the social sciences] (10. baskı). Seçkin Yayıncılık. 


\section{Ankara University Faculty of Educational Sciences Journal of Special Education}

2022, 23(1), 133-164
RESEARCH

Recieved Date: 26.08.20

Accepted Date: 30.05 .21

OnlineFirst: 10.07.21

\title{
Expert Perspectives on Distance Special Education Interventions for Students with Special Needs and Their Families in Turkey During the COVID-19 Pandemic
}

\author{
Sunagül Sani-Bozkurt ${ }^{\text {iD }} 1$ \\ Gizem Yıldız iD 4 \\ Çiğdem Uysal ${ }^{i D}$ ? \\ Özlem Diken 10 \\ Murat Doğan 13
}

\author{
Gülden Bozkuş-Genç ${ }^{D}{ }_{2}$ \\ Seçil Çelik 5 \\ Hasan Gürgür iD 8 \\ Nazmiye Nazlı Ateşgöz 11 \\ Pınar Şafak 14
}

\author{
Sezgin Vuran ${ }^{1}{ }_{3}$ \\ İbrahim H. Diken ${ }^{D} 6$ \\ Gülefşan Özge Kalaycı 9 \\ Rifat İçüz 12 \\ Pınar Demiryürek 15
}

\begin{abstract}
Introduction: In this study, it was aimed to reveal the distance special education interventions carried out for students with different special needs and their families in Turkey during the restriction period due to the coronavirus (COVID-19) pandemic through expert perspectives. When schools were closed during COVID-19, the changing lives negatively affected not only students with special needs but also their families.
\end{abstract}

Method: In this study which was designed as a collective case study, a total of 15 academics constituted the direct participants of the study to report their own experiences and observations.

Findings: According to the results of the study, it was observed that distance education-based interventions for students with special needs and their families were provided by official, private institutions and individuals along with the rapid transition to distance education in Turkey. The interventions were not systematic in that they could not be spread across the country. This clearly demonstrated that there were lessons to be learned from this process, such as enriching mobile applications for each disability group, and establishing family-oriented support mechanisms.

Discussion: It is predicted that the results of the study may help to draw a forward-looking road map in planning special education interventions in different countries, especially in Turkey. In response to the lockdown conditions, the special education practice in Turkey has become one of the good examples in the process of transition. In the study, suggestions were presented to decision makers, schools, institutions, experts, and families.

Keywords: Coronavirus, COVID-19, distance education, emergency remote teaching, students with special needs, psychosocial support, special education.

To cite: Sani-Bozkurt, S., Bozkuş-Genç, G., Vuran, S., Yıldız, G., Çelik, S., Diken, İ. H., Uysal, Ç., Gürgür, H., Kalaycı, G. Ö., Diken, Ö., Ateşgöz, N. N., İçü̈z, R., Doğan, M., Şafak, P., \& Demiryürek, P. (2022). Expert perspectives on distance special education interventions for students with special needs and their families in Turkey during the COVID-19 pandemic. Ankara University Faculty of Educational Sciences Journal of Special Education, 23(1), 133164. https://doi.org/10.21565/ozelegitimdergisi.786118

\footnotetext{
${ }^{1}$ Corresponded Author: Assist. Prof., Anadolu University, E-posta: ssbozkurt@anadolu.edu.tr, https://orcid.org/0000-0001-6648-9636

${ }^{2}$ Assist. Prof., Anadolu University, E-mail: guldenbozkus@anadolu.edu.tr, https://orcid.org/0000-0002-9444-7393

${ }^{3}$ Prof., Anadolu University, E-mail: svuran@ anadolu.edu.tr, https://orcid.org/0000-0001-7658-1102

${ }^{4}$ Dr., Anadolu University, E-mail: gizemy@ anadolu.edu.tr, https://orcid.org/0000-0003-2693-6264

5Dr., Anadolu University, E-mail: secilcelik@ anadolu.edu.tr, https://orcid.org/0000-0002-1393-3382

${ }^{6}$ Prof., Anadolu University, E-mail: ihdiken@anadolu.edu.tr, https://orcid.org/0000-0002-5761-2900

${ }^{7}$ Res. Assist., Anadolu University, E-mail: cigdemkol@ anadolu.edu.tr, https://orcid.org/0000-0002-7884-8728

${ }^{8}$ Prof., Anadolu University, E-mail: hasangurgur@anadolu.edu.tr, https://orcid.org/0000-0002-4016-4048

${ }^{9}$ Res. Assist., Anadolu University, E-mail: gulefsanozgeakbey@anadolu.edu.tr, https://orcid.org/0000-0002-7627-8477

${ }^{10}$ Prof., Anadolu University, E-mail: odogramaci@anadolu.edu.tr, https://orcid.org/0000-0003-1676-7989

${ }_{11}^{11}$ Assist. Prof., Anadolu University, E-mail: nazmiyeo@anadolu.edu.tr, https://orcid.org/0000-0001-5944-937X

${ }^{12}$ Res. Assist., Anadolu University, E-mail: rifaticyuz@anadolu.edu.tr, https://orcid.org/0000-0003-1279-3936

${ }^{13}$ Assoc. Prof., Anadolu University, E-mail: mudogan@anadolu.edu.tr, https://orcid.org/0000-0003-4942-3760

${ }^{14}$ Assoc. Prof., Gazi University, E-mail: apinar@gazi.edu.tr, https://orcid.org/0000-0002-3386-9816

${ }^{15}$ Res. Assist., Gazi University, E-mail: pdemiryurek@ gazi.edu.tr, https://orcid.org/0000-0003-1035-5246
} 


\section{Introduction}

The Coronavirus (COVID-19) pandemic has not only affected the public health for the first time due to its scale and effect all over the world (Organisation for Economic Cooperation and Development [OECD], 2020), it has also significantly affected every aspect of our daily life. In this sense, education has been one of the areas most affected by the COVID-19 pandemic (Bozkurt et al., 2020; United Nations Educational, Scientific and Cultural Organization [UNESCO], 2020a, 2020b). Educational institutions at all levels around the world were also immediately closed to slow down the spread of the COVID-19 pandemic. Therefore, the education of 1.6 billion students, equal to approximately $90 \%$ of the student population around the world, was interrupted (UNESCO, 2020a; 2020b; United Nations Children's Fund [UNICEF], 2020). This enormous effect of COVID-19, which is the biggest challenge faced by national education systems, on access to education has caused significant pressure on education all over the world. Many countries, including Turkey, are still making efforts to maintain their educational processes and to create, update and develop distance education platforms (Goldschmidt, 2020; OECD, 2020; Özer, 2020).

The lives that changed when schools were closed during the COVID-19 pandemic adversely affected not only students with special needs but also their families (Asbury et al., 2020). Families are highly affected by such a process within a psycho-social context, depending on various socio-demographic variables, domestic life, and especially gender roles and duties (Işık \& Akbaş, 2019). Beyond restriction, the home education process is still going on, and it will be necessary to shape its new norm to find out the needs for the support of students, who are preparing to return to school in the near future, and their families (Toseeb et al., 2020) and to address distance special education interventions from a broader perspective. It is necessary to learn lessons from the current situation so that preparations and updates can be made based on the needs of students with special needs and their families. On the other hand, considering the high probability of the emergence of the second wave of the pandemic, the necessity to prepare for the process as a precaution can be emphasized. Therefore, there is an urgent need for comprehensive studies that summarize and synthesize the situation to reveal the shortcomings and strengths of the existing studies on distance special education interventions during the COVID-19 restriction period. Thus, a basic framework will also be drawn on what can be done in the case of new pandemics in the future by revealing the existing situation.

Based on this justification, this study aimed to reveal special education interventions carried out for different special needs conditions (autism spectrum disorder [ASD], intellectual, hearing, visual, speech and language disorder, attention deficit and hyperactivity disorder [ADHD] and giftedness) in Turkey during the restriction period due to the COVID-19 pandemic through expert perspectives. To this end, answers to the following research questions were sought: (a) What are the interventions carried out in the field of distance education in different special needs groups? (b) What are the interventions carried out within the psycho-social context in the distance education process in different special needs groups? (c) What are the lessons to be learned from the pandemic within the scope of distance education interventions in different special needs groups?

\section{Method}

The collective case study (Stake, 1995), one of the qualitative research approaches, was adopted within the scope of the aim of this study. In the study conducted as a collective case study, each contribution to seven special needs groups was examined under the same three subtitles. It was ensured that readers examined the cases independently or compared them with each other (Bartlett \& Vavrus, 2016; Stake, 1995). In this context, seven cases within the context of ASD, intellectual disability, hearing and visual impairment, speech and language disorder, ADHD and giftedness were examined in the study. To this end, each case was examined by receiving the opinions of field experts under the umbrella of special needs within the context of "reflections in distance education", "reflections in psycho-social support" and "the lessons to be learned from the pandemic" during the restriction period. A group of 15 academics with a researcher and practitioner identity who had approximately 630 years of experience in the field of education to report their own experiences and observations on each case were involved in the research process. These individuals are also the authors of the article. The purpose of keeping the academician group large was to present a large number of researcher observations and a pluralistic perspective in the context of the research subject. In this study, each of the researchers is a direct participant of the study.

In the study, data collection was performed through phone calls/conversations with the families, teachers, students, and institutional coordinators who reached them during the pandemic, especially the researcher's observations, institutional websites, written reports, documents, archive records, student products (artistic works, materials created and other physical evidence that can be used in the study), photographs, video records, and social 
media platforms. After the data collection process, the data obtained by the academics were filtered, the differences and patterns were searched, and the observations and experiences were written with a heuristic perspective.

\section{Results}

\section{Case 1: Autism Spectrum Disorder (ASD)}

The Ministry of National Education (MoNE) and leading non-governmental organizations (NGOs) that directly provide services to students with ASD conducted online webinars, link sharing to resources, access to the recordings of the seminars on YouTube channel, interviews, family education, and awareness studies. When it comes to students with ASD, it can be said that the programs and materials directly for these students are quite limited. The contents were presented to students with ASD through visual aids and interactive applications. Special education course contents were prepared by considering that all students with ASD had similar cognitive characteristics. Deciding on which mobile applications would be suitable for students with ASD, and the needs for guidance and counseling on how families could use the contents were left to the individual efforts of the families. Unfamiliarity with distance education interventions that were introduced suddenly, anxiety to support students, the possibility of unemployment for teachers/experts working in private education institutions, dealing with financial concerns and social and psychological difficulties caused by the pandemic in their own lives made this process very stressful and tiring for teachers/experts. The most common stresses and anxieties experienced by students with ASD and their families were the disruption of family routines, the disappearance of socialization efforts, behavioral problems, anger attacks and increased stereotypes, sleep and eating disorders. Furthermore, they had TV, tablet and phone addiction, increased need for expert guidance, and anxiety of "What will happen to my child?" in case of death due to COVID-19.

\section{Case 2: Intellectual Disability}

It is observed that separate sections called "Intellectual Disability and Inclusion" and "Intellectual Disability and Education Plan" were created for students with intellectual disability and their families on the EBA platform. In these sections, it was observed that categorization was made according to grade levels, not as mildmoderate-severe intellectual disability, and that many lectures and practical activity videos related to academic courses focusing on teaching the concepts and skills to older age groups were mainly embedded in these categories. It is remarkable that a limited number of materials for the early childhood/preschool age group were included at grade levels. Furthermore, it was also observed that while the instructions and video shooting angles in some activities prepared for students with intellectual disability were not clear, the duration of the activities was long. Some of the lectures, in which the direct instruction method was generally used, remained abstract, the expert consultancy was not included. It was time-consuming to open videos and images due to the infrastructure. The studies of various non-governmental organizations, in addition to the MoNE, have also gained momentum during the pandemic in Turkey. However, individuals started to exhibit behaviors, such as withdrawal, depression, continuous sleepiness, and addiction to technological devices like computers, mobile phones and tablets, as a result of spending such a long time at home for the first time in their lives. In this process, the biggest source of stress was the intense sense of loneliness due to the lack of peer interaction and being stuck at home. In addition to the economic problems due to leaving the job, parents felt helpless and started to seek support since they could not access guidance services due to the cessation of the diagnostic assessment process, especially in the 0-3 age period.

\section{Case 3: Hearing Impairment}

Families pointed out that the live courses conducted by teachers, who provided training for students with hearing impairment, especially regarding language and communication skills via Zoom in an inclusive education environment as the distance education process progressed very quickly. Therefore, they indicated that students had difficulty in following the course contents. Thus, it was observed that teaching materials and instructional design were insufficient to meet the individual needs of students with hearing impairment. Teacher and student interactions with those with hearing impairment were limited, especially in inclusive education environments. The lessons finished with a brief evaluation following the instruction. The failure to meet the needs of the students with hearing impairment in the development of language and communication skills due to their characteristics and their socialization needs increased problems such as family stress and unhappiness as they could not be present in the social environment. From this point of view; psychological services, family education and therapy sessions provided by the government could be helpful. During the restriction period, public institutions, municipalities, NGOs and some private communities also provided support services for students with hearing impairment to minimize the negative effects of the pandemic. 


\section{Case 4: Visual Impairment}

During the distance education period, students with visual impairment had some difficulties in following the courses. They needed more time due to some reasons such as few or no description in lessons, displaying the picture/photograph (image) on the screen for a very short time, and reading the questions partially (such as question stems) instead of presenting these questions as a whole. Furthermore, students with low vision had to take a photograph of the screen with the phone and then enlarge it to see the images on the screen. However, it was not possible as some images remained on the screen for a very short time. While such problems were experienced in lectures on EBA TV, accessibility problems were also observed in the EBA application. It was observed that students with low vision had difficulty in vision as the fonts of the articles in the application were not large enough along with the issues of poor clarity and contrast in visuals. In addition to such problems, especially students with low vision also indicated that the EBA application was important in that they could catch up with the content of the lessons. Families attempted to make descriptions of the visuals by watching the lessons with their children. However, this was not possible for every family, which caused the student to miss what was told as they were unable to focus. These students had particular difficulties in the questions including figures in quantitative lessons and English lesson. These students and their families benefited little from social support groups during the pandemic. Some families attempted to watch the live chats of experts on the internet to receive support. Following this, the families were reported to hold the expectation that this support would continue after the pandemic as well.

\section{Case 5: Speech and Language Disorders}

During the restriction period, interruptions were observed in the goal-setting process and achievements before the pandemic among students with language and speech difficulties in hospitals. Some intervention practices were seen to be insufficient due to the inability to communicate face to face with these students. In the interventions modeling lip-tongue movements (in the case of speech sound disorders management), the speech and language therapist was concerned about whether he/she was able to transfer the model of the target sound exactly through the image. Although support was received from the family in the interventions requiring tactile stimuli such as prompt, the intervention could not be carried out fully and effectively. During this process, family members had to take the responsibility of the educator/therapist along with their parental responsibilities. This caused them to experience a sense of burnout. Families received support from experts through video interviews about what strategies they could implement in the home environment to cope with the problems they faced. The active use of social media by experts during this process also supported families concerning guidance and using appropriate strategies. At the request of the families, some of the speech and language therapists continued their sessions by visiting the home environment of the students. During this process, speech and language therapists took the necessary measures, prepared masks with a transparent lip and performed their sessions by following the rules of mutual hygiene and social distancing.

\section{Case 6: Attention Deficit and Hyperactivity Disorder (ADHD)}

It was observed that teachers communicated with families and helped them regarding many issues such as how to motivate students with ADHD to attend and follow live courses, and what the environment setting should be from the beginning of the pandemic. In this regard, teachers indicated that most of the families with children with ADHD were voluntary and maintained healthy communication throughout the process. It was stated that social media was used too much to communicate with each other and that when some contents were not at the developmental level of their children or were not sufficient, teachers designed activities and materials with families. In general, it appeared that all teachers or experts made significant efforts to reach and support each student with ADHD from the beginning of the process. Due to staying at home, routine activities planned especially for young students to release their energy were disrupted, and interpersonal interactions were prevented. Moreover, these students had difficulty in understanding why they should stay home.

\section{Case 7: Giftedness}

EBA includes short videos prepared by academics working in the field of gifted education to inform families and teachers. However, there is no separate section for gifted students. Furthermore, it was observed that the teachers working in resource room for gifted students at primary schools and the teachers of Science and Art Centers (SAC) could not form a group with their own students on EBA. Therefore, they could not use EBA. The families of gifted students also indicated that EBA contents in formal education were easy for children. However, children effectively benefited from the interventions presented by teachers working in resource rooms or SAC. Gifted students did research in individual areas of interest and developed various projects. Gifted students studying 
at different levels from primary school to high school level could easily adapt to the online education process due to their high level of digital skills and high level of motivation. Teachers and families also had the opportunity to improve themselves in the context of technology. Especially gifted students at primary school improved their skills such as time management and individual study during the distance education process. However, the use of technological devices such as computers and tablets became quite intensive among some gifted students. The assessment and evaluation process was also quite insufficient during the distance education process.

\section{Discussion}

The results of this first study in the field evaluated the state of special education interventions among different special needs groups in Turkey during the COVID-19 pandemic. The study also provided data in a holistic and comprehensive manner. In the following, the content of distance education, mobile applications, assessment and evaluation, changing roles and responsibilities, psycho-social support needed in distance education, digital literacy skills and digital inequality/divide stood out as the focal points in the reflections of experts. Especially the results of "changing roles and responsibilities" and "need for expert support" were similar to the results of previous studies (Asbury et al., 2020; Stankovic et al., 2020; Toseeb et al., 2020). These results are often explained by the anxieties experienced by students with special needs and their families during the home education process. As stated in the literature, it was observed that sudden changes and anxiety among students with special needs and their families in terms of their behaviors came to the forefront as a result of rapid social changes and school closures that occurred in the restriction process (Asbury et al., 2020; Stankovic et al., 2020).

The results of the study showed that these anxieties experienced with the introduction of distance education were similarly reflected in the seven special needs groups. In this case, the effects of the pandemic on the mental health of students with special needs at the moment can be considered as an extremely worrying situation. For example, it is also indicated that individuals with ASD seriously feel the effects of being socially isolated and lonely (Pelton et al., 2020), are more stressed and prone to suicide compared to typically-developing individuals (Bishop-Fitzpatrick et al., 2017; Cooper et al., 2017). Similar to the findings of the study conducted by Stankovic et al. (2020), these behavioral changes due to worry, anxiety and stress among ASD were frequently mentioned by families. However, it should also be stated that these behavioral changes manifest themselves with uneasiness, behavioral problems, sleep problems, inability to adapt to domestic routines (especially in the young age group).

In this study, the changing family roles and responsibilities, along with the rapid transition to distance education, stood out as one of the issues particularly emphasized in all special needs groups. The results of the studies conducted both in Turkey and other countries indicated that when parents took on their children's educational roles in their daily routine, they had difficulty in accessing information due to reasons such as the limited internet, inability to use technological tools, and inability to review all resources via a single portal. This increased their stress and anxiety levels (Courtenay \& Perera, 2020; Douglas et al., 2020; Goldschmidt, 2020; Özer, 2020; Rose et al., 2020). It is emphasized that family role expectations diversified and increased when parents assumed the role of educators at home (Bozkurt et al., 2020; Burke \& Dempsey, 2020; UNESCO, 2020b). In particular, the increase in problem behaviors of students with special needs who had to frequently spend time with online educational materials and whose routines were changed along with the coping strategies of parents were mentioned (Alexander et al., 2020; Courtenay \& Perera, 2020; Rose et al., 2020). In Turkey where family education services are not compulsory even in early childhood, it can be said that the coping strategies used by parents, perhaps most intensively, with both digital literacy skills and behavioral problems were realized by supporting each other through social media accounts, expressing their problems, expectations and demands, and criticizing the policymakers, experts and teachers.

Although students with special needs and their families needed different support within the context of their characteristics during the pandemic process, it is indisputable that emotional support is important for both students and their families. When it is considered that education is the second priority and care is the basic need of people especially in traumatic times, according to the approach called the pedagogy of care, (Noddings, 2012), it is recommended that revealing appropriate interventions should be considered as the first priority. According to Bozkurt and Sharma (2020), although the transition to distance education is important to ensure the continuity of education, students will remember how they felt during this process rather than educational content in the new normal after COVID-19. Therefore, it is strongly emphasized that the pedagogy of care in distance education interventions is important in terms of meeting the resulting emotional/affective needs (Robinson et al., 2020). 
Thus, students with special needs and their families will be able to overcome the difficulties caused by COVID19 with minimal damage.

Another remarkable issue for students with special needs and their families to overcome the difficulties caused by COVID-19 with minimal damage is that the distance education process should be designed within the scope of inclusive education based on the idea that no student will be left behind in education, as in face-to-face education. Inclusive education gives equal importance to all students' access to educational processes and the materials prepared (Ackah-Jnr, 2020; Armitage \& Nellums, 2020). The preparation of distance education studies for students with special needs and their families based on this approach has become one of the important pandemic agendas in Turkey as well as all over the world (Armitage \& Nellums, 2020; Berger et al., 2020; Bozkurt et al., 2020; Özer, 2020). The inclusion of planning for distance education in cases when education and training are interrupted in the Special Education Services Regulation in Turkey, and the employment of many studies based on distance education under the guidance of the MoNE and in cooperation with a wide range of non-governmental organizations, teachers and experts are the consequences of this approach (Kavak, 2020; Özer, 2020).

Although distance education interventions have positive features in terms of reaching many people in the country or even between countries at the same time and being able to follow individuals based on their personal time, they also bring along some issues that need to be discussed (Pineda \& Corburn, 2020; Singh, 2020; Thelwall \& Levitt, 2020). Another issue on which too much stress was laid, especially along with the need for the diversification of content materials, in the results of this study, was that assessment and evaluation systems could not be implemented in this process and were left to result-oriented decisions/initiatives. Along with the transition to distance education due to COVID-19, the assessment and evaluation processes based on pass-fail grading were suspended (Bozkurt et al., 2020), or it was required to hold online exams suddenly without adequate validity and reliability studies in many countries (d'Orville, 2020). Therefore, it is observed that the plans made are insufficient in this regard.

Another important issue to be emphasized is that adaptation to the new norm of online education in the COVID-19 pandemic raised the risk of emphasizing and reinforcing the social divide. The social divide arises from the digital divide. Equal access to information is one of the priority issues to be considered in this context (Courtenay \& Perera, 2020; Pineda \& Corburn, 2020; Singh, 2020). The educational policies in Turkey aimed to have a widespread effect by developing many distance education platforms for students with special needs, their families and experts during the pandemic process. However, there were problems in reaching stakeholders in every region of Turkey (Özer, 2020). The first one of these problems is the lack of technological tools and competencies of those from low socioeconomic levels and the lack of the internet service network or limited access to the internet. Another problem is that even if there is internet access, there are problems in the opening and smooth operation of applications based on visual activities and games due to the infrastructure and internet speed.

In conclusion, while the design of distance education studies with features aiming at the widespread effect with the philosophy that every student is important in Turkey, issues such as accelerating the work of NGOs, strengthening the internet infrastructure, enriching the materials developed and ensuring full accessibility are still waiting to be solved. Nevertheless, it can be said that this sudden and short transition to distance education was responded rapidly during the restriction process in Turkey, it was managed with a planned transition, and there were examples of good interventions during this period. It can be said that careful but quick regulations carried out by public institutions across the country have been generally influential. However, there is a need for a call to accelerate the efforts of experts working in the field of special education, especially decision-makers, and all relevant stakeholders. Further efforts are needed to ensure that the plans made on the distance education platform are addressed separately in special needs groups. In this context, the rights of students with special needs, such as education and social services, should be protected within the scope of the COVID-19 pandemic, and new action plans should be created within the scope of the pandemic. In fact, this situation should not only be within the scope of the pandemic but should be addressed in a way to cover emergencies or extraordinary situations as Turkey has a geographic structure in which natural events are common and continue to be experienced due to previous and frequent natural disasters such as floods, landslides and earthquakes. In this respect, the collection of quantitative and qualitative data to identify the basic needs of students with special needs and their families in Turkey is needed for the resolution and planning of many issues. To ensure that these plans are inclusive/holistic and are realized will require meaningful consultation with students with special needs and their supporters, leadership at the policy and program level, and specific budget lines. 


\section{Author's Contributions}

The first author of the study identified the subject of the study, the method and design of the research, and took part in data collection, data analysis and reporting the findings of the study. Other authors took part in data collection, data analysis and reporting the findings of the study.

\section{Acknowledgment}

We would like to thank the institution coordinators, teachers and families with children with special needs who provided information for our research during the pandemic. 